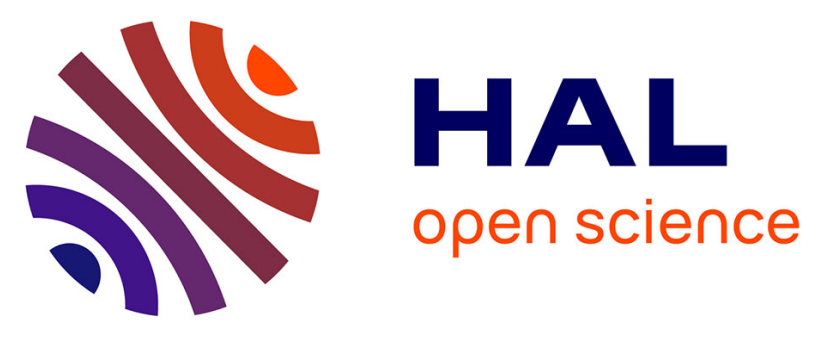

\title{
Climate versus human-driven fire regimes in Mediterranean landscapes: the Holocene record of Lago dell'Accesa (Tuscany, Italy)
}

\author{
Boris Vannière, D. Colombaroli, Emmanuel Chapron, A. Leroux, Willy \\ Tinner, Michel Magny
}

\section{To cite this version:}

Boris Vannière, D. Colombaroli, Emmanuel Chapron, A. Leroux, Willy Tinner, et al.. Climate versus human-driven fire regimes in Mediterranean landscapes: the Holocene record of Lago dell'Accesa (Tuscany, Italy). Quaternary Science Reviews, 2008, 27, pp.1181-1196. 10.1016/j.quascirev.2008.02.011 . insu-00446317

\section{HAL Id: insu-00446317 https://hal-insu.archives-ouvertes.fr/insu-00446317}

Submitted on 18 Jan 2010

HAL is a multi-disciplinary open access archive for the deposit and dissemination of scientific research documents, whether they are published or not. The documents may come from teaching and research institutions in France or abroad, or from public or private research centers.
L'archive ouverte pluridisciplinaire HAL, est destinée au dépôt et à la diffusion de documents scientifiques de niveau recherche, publiés ou non, émanant des établissements d'enseignement et de recherche français ou étrangers, des laboratoires publics ou privés. 


\title{
Climate versus human-driven fire regimes in Mediterranean landscapes: the Holocene record of Lago dell'Accesa (Tuscany, Italy)
}

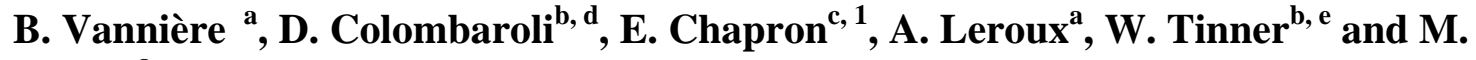 \\ Magny $^{a}$
}

${ }^{a}$ Chrono-Environment Laboratory, UMR 6249 CNRS-UFC, 16 route de Gray, F-25030 Besançon cedex, France

${ }^{\mathrm{b}}$ Paleoecology, Institute of Plant Sciences, University of Bern, Altenbergrain 21, CH-3013 Bern, Switzerland

${ }^{\mathrm{c} G e o l o g i c a l ~ I n s t i t u t e, ~ E T H ~ Z u ̈ r i c h, ~ U n i v e r s i t a ̈ t s t r a s s e ~ 16, ~ C H-8092 ~ Z u ̈ r i c h, ~ S w i t z e r l a n d ~}$

${ }^{\mathrm{d}}$ Environmental Change Research, Department of Geography, University of Oregon, Eugene, OR 97403-1251, USA

${ }^{\mathrm{e}}$ Paleoecology and Vegetation Dynamics, Department of Environmental Sciences, Institute of Terrestrial Ecosystems, ETH Zürich, Universitätsstrasse 22, CH-8092 Zürich, Switzerland

${ }^{1}$ ISTO, UMR 6113, CNRS Université d'Orléans, B.P. 6759, F-45067 Orléans cedex 2, France.

\begin{abstract}
A high-resolution sedimentary charcoal record from Lago dell'Accesa in southern Tuscany reveals numerous changes in fire regime over the last $11.6 \mathrm{kyr}$ cal. BP and provides one of the longest gap-free series from Italy and the Mediterranean region. Charcoal analyses are coupled with gamma density measurements, organic-content analyses, and pollen counts to provide data about sedimentation and vegetation history. A comparison between fire frequency and lake-level reconstructions from the same site is used to address the centennial variability of fire regimes and its linkage to hydrological processes. Our data reveal strong relationships among climate, fire, vegetation, and land-use and attest to the paramount importance of fire in Mediterranean ecosystems. The mean fire interval (MFI) for the entire Holocene was estimated to be $150 \mathrm{yr}$, with a minimum around $80 \mathrm{yr}$ and a maximum around $450 \mathrm{yr}$. Between 11.6 and $3.6 \mathrm{kyr}$ cal. BP, up to eight high-frequency fire phases lasting 300 $500 \mathrm{yr}$ generally occurred during shifts towards low lake-level stands (ca 11,300, 10,700, $9500,8700,7600,6200,5300,3400,1800$ and 1350 cal. yr BP). Therefore, we assume that most of these shifts were triggered by drier climatic conditions and especially a dry summer season that promoted ignition and biomass burning. At the beginning of the Holocene, high climate seasonality favoured fire expansion in this region, as in many other ecosystems of the northern and southern hemispheres. Human impact affected fire regimes and especially fire frequencies since the Neolithic (ca 8000-4000 cal. yr BP). Burning as a consequence of anthropogenic activities became more frequent after the onset of the Bronze Age (ca 38003600 cal. yr BP) and appear to be synchronous with the development of settlements in the region, slash-and-burn agriculture, animal husbandry, and mineral exploitation. The
\end{abstract}


anthropogenic phases with maximum fire activity corresponded to greater sensitivity of the vegetation and triggered significant changes in vegetational communities (e.g. temporal declines of Quercus ilex forests and expansion of shrublands and macchia). The link between fire and climate persisted during the mid- and late Holocene, when human impact on vegetation and the fire regime was high. This finding suggests that climatic conditions were important for fire occurrence even under strongly humanised ecosystem conditions.

\section{Introduction}

Fire is one of the most relevant agents of disturbance for it significantly affects vegetation cover, soils, and biodiversity at decadal to centennial scales (e.g. Moreno, 1998; Buhk and Hensen, 2006; Campo et al., 2006; Pausas, 2006; Shakesby and Doerr, 2006; Baeza et al., 2007). The role of fire for future ecosystem dynamics is underlined by the evidence that predicted climate warming will probably affect future fire dynamics (Piňol et al., 1998; Cramer, 2001; Moriondo et al., 2006; Running, 2006), given that fire severity and fire-surface extent are also climatically driven (Pausas, 2004; Keeley et al., 2006). However, many lines of evidence show that fire regime changes are not linearly linked to climatic change, for instance declines of fire frequency as a consequence of climatic warming are documented by long-term ecological and modelling studies from the Boreal biome (e.g. Bergeron and Archambault, 1993; Flannigan et al., 1998; [Tinner et al., 2006a] and [Tinner et al., 2006b]). On a longer-time perspective, fire hazard has generally increased due increases in population size since prehistory, changes in husbandry practices, and increases in human ignition sources (Clark et al., 1989; Tinner et al., 1999; Carcaillet et al., 2002).

Despite the relevant role of human activities during the past millennia and today (e.g. ignition or fire-suppression management; Terradas et al., 1998), fire regimes, defined in terms of severity, frequency, extent, in forested areas of the Mediterranean region and elsewhere are also linked to hydrologic conditions and seasonality that are in turn related to large-scale atmospheric circulation patterns (Heyerdahl et al., 2002; Veblen and Kitzberger, 2002; Trouet et al., 2006). For instance, besides a specific source of ignition, burning depends on the span and degree of the dry season (fuel flammability), but also on fuel availability, which often increases after wet years (Pausas, 2004; Pausas and Bradstock, 2007).

Fire-landscape interactions are still scarcely understood because of the complexity of fire ignition and propagation processes (Mouillot et al., 2003; Arora and Boer, 2005; Salvador et al., 2005; Cary et al., 2006; Heinl et al., 2006; Santoni et al., 2006). During recent decades fire-history studies from the Pacific Northwest of North America, as well as South America, Australia, and central and boreal Europe have progressively contributed to the present knowledge about Holocene fire-climate-vegetation-human interactions (e.g. Clark and Royall, 1996; Carcaillet, 1998; Pitkanen and Huttunen, 1999; Millspaugh et al., 2000; Long and Whitlock, 2002; Brunelle and Anderson, 2003; Brunelle and Whitlock, 2003; Lynch et al., 2003; Tinner et al., 2005; Black and Mooney, 2006; Gavin et al., 2006; Hu et al., 2006). Surprisingly, few data are currently available from the Mediterranean Basin (Carcaillet et al., 1997; Carrión, 2002; [Carrión et al., 2003] and [Carrión et al., 2007]; Sadori et al., 2004; Caroli and Caldara, 2006; Magny et al., 2006; Sadori and Giardini, 2006), most of them having low temporal resolution and/or precision. In fact, only a few studies have high enough precision and resolution (i.e. 10-20 yr, Birks, 1997) to address fire-vegetation linkages such as the role of fire in driving vegetational dynamics (e.g. [Colombaroli et al., 2007] and [Colombaroli et al., in press]). Therefore, most studies focus on long-term (millennial) trends to study linkages between fire and climate. 
This paper aims to improve our knowledge about the linkages between Holocene fire regimes, climatic conditions, vegetation, and land-use history in the central Mediterranean. First, we present a high-resolution charcoal sequence from Lago dell'Accesa (Tuscany, Italy). We quantify the long-term charcoal accumulation anomalies along the temporal scale by means of inferred fire frequency (IFF), fire return interval (FRI), and mean fire interval (MFI), estimated according to events interpreted as local fire episodes (Clark et al., 1996; Long et al., 1998; Lynch et al., 2003; Whitlock and Anderson, 2003; Brunelle et al., 2005). We then compare these results with pollen data, lake-level reconstructions and archaeological data to understand to what extent the centennial variability of fires is controlled by climatic, environmental, and/or anthropogenic factors.

\section{Study area}

Lago dell'Accesa $\left(42^{\circ} 59^{\prime} 17^{\prime \prime} \mathrm{N}, 10^{\circ} 53^{\prime} 44^{\prime \prime} \mathrm{E}, 157 \mathrm{~m}\right.$ a.s.1.) is a small lake situated in the southern part of Tuscany (north-central Italy), $5 \mathrm{~km}$ from the town of Massa Marittima and $12 \mathrm{~km}$ from the Mediterranean Sea coast (Fig. 1a). Vegetation around Lago dell'Accesa is characterised by mixed evergreen/deciduous forests (e.g. Quercus ilex, Q. pubescens). Annual precipitation reaches ca $745 \mathrm{~mm} / \mathrm{yr}$, with a maximum during autumn and a marked summer drought. The average annual temperature is ca $13{ }^{\circ} \mathrm{C}$, the mean temperature of the coldest month is $4.5^{\circ} \mathrm{C}$ and that of the warmest month $22^{\circ} \mathrm{C}$ (Rizzotto, 1981). The lake basin (ca $580 \times 390 \mathrm{~m}$ ) is of karstic origin and is fed by a sub-aerial and a sub-aqueous thermal spring (ca $20^{\circ} \mathrm{C}$; Fig. 1b). Its outlet marks the beginning of the Bruna River. The bathymetric map reveals a maximum depth of $37.5 \mathrm{~m}$. The lacustrine profiles indicate a littoral sub-horizontal zone ca 5-20 m wide. Below, there is a steep slope, and finally a gentle slope that reaches the sub-horizontal deepest part of the lake basin (Fig. 1c). The catchment area of the lake covers ca $5 \mathrm{~km}^{2}$ and is delimited by small hills culminating at ca $350 \mathrm{~m}$ a.s.l. The geology of the catchment area is characterised by Permian and Eocene schists and karstified Rhaetian dolomitic limestone (Merciai, 1933). In 1912, the lake level was artificially lowered to extend arable lands, and this diminished significantly the immerged littoral platform.

Several artifacts and archaeological remains have been found in the neighbourhood of the lake. The most important ones are situated on the eastern hill slope, where a necropolis and a settlement from the Etruscan period have been excavated. It is likely that the settlement was connected to the exploitation of the nearby metal deposits. This mining village lasted about a century, from ca 2600 to 2500 cal. yr BP (Lobell, 2002). Several other artifacts, such as potsherds, indicate that the area was continuously occupied by humans since the Neolithic. In historic times the lake water was used to wash minerals from the island of Elba or from regional and local mines (Rizzotto, 1981).

After an early rapid survey in 1984 (R. Drescher-Schneider, unpublished pollen data), and following investigations of the Holocene and Lateglacial littoral deposits in 2000 (Magny et al., 2006; Drescher-Schneider et al., 2007; Magny et al., 2007; Millet et al., 2007), a new coring campaign was organised in 2005 to obtain a continuous Holocene sedimentary sequence from the deepest part of the lake.

\section{Materials and methods}




\subsection{Mapping and coring}

Bathymetric map and seismic profiles (Figs. 1b and c) were constructed with a highresolution single-channel seismic system with a centre frequency of $3.5 \mathrm{kHz}$ (Geoacoustic Equipment). The digital acquisition was achieved by an Octopus Marine 360 system and conventional GPS positioning. The acoustic data highlight a specific acoustic facies associated with the steep littoral environments, which progrades towards the centre of the lake. From these littoral environments, locally reworked sediment slumps produced lensshaped bodies with a chaotic facies (Fig. 1c), intercalated in the acoustically stratified deposits characterising the deep basin. Below $23 \mathrm{~m}$ water depth the stratified basin fill has a dominating draping pattern and is made of several high-amplitude basin-wide reflectors (R1 to R7) that are locally associated with slump deposits or covering a former littoral facies. These geometries reflect the evolution of a dominating bio-induced sedimentation controlled by inputs from the springs and/or lake-level fluctuations. Unfortunately, gas in the deep basin limits the acoustic signal penetration to ca $5 \mathrm{~m}$ below the lake floor. Coring operations were directly guided by the quasi-3D image of subsurface sedimentary accumulation. Short $(1 \mathrm{~m})$ and long $(8 \mathrm{~m})$ sediment cores were retrieved from the best stratified and undisturbed parts of the deep-basin sedimentary infilling with the ETH short gravity corer and a $3 \mathrm{~m}$ long UWITEC piston system operating from a raft (Fig. 1c). This study refers to the overlapping twin cores $\mathrm{AC} 05-\mathrm{P} 6, \mathrm{AC} 05-\mathrm{B}^{*}$ and $\mathrm{AC} 05-\mathrm{BB}^{*}$, which provided the temporally longest sedimentary sequence AC05-B.

\subsection{Chronology}

The chronology is based on $12 \mathrm{AMS}{ }^{14} \mathrm{C}$ ages measured on terrestrial plant macrofossils (Table 1). Macrofossils were selected from 70 sediment samples (volume ca $20 \mathrm{~cm}^{3}$; mean thickness of $5 \mathrm{~cm}$ ) which were sieved with a $100-\mu \mathrm{m}$ mesh screen. After calibration of the ${ }^{14} \mathrm{C}$ dates (program Calib 5.0.2; Stuiver and Reimer, 1993; Reimer et al., 2004), one radiocarbon date was rejected (Poz-16244) on the basis of a reliability of stratigraphy test, as implemented in the program Oxcal 3.10 (Ramsey, 2001). The age-depth model is constructed with a cubicspline interpolated method (Fig. 1d; Telford et al., 2004). The near-optimal number of degrees-of-freedom has been chosen to keep the interpolated chronological curve within the confidence interval of the generalised mixed-effect regression as proposed by Heegard (Birks and Heegaard, 2003; Heegaard et al., 2005) as well as to force the age-depth model to pass through the error range of the calibrated ages.

\subsection{Sedimentology}

Gamma density (GD) measurements were made on each $5 \mathrm{~mm}$ on the whole core with the Geotek Multi Sensor Core Logger. Bulk density is derived from gammaray attenuation measurements after calibration. Hand-made density measurements show a constant difference of $0.3 \mathrm{~g} / \mathrm{cm}^{3}$, which have been added to obtain the final results. The rapidity of this analysis allows measuring all the core sections sampled in the lake and then makes stratigraphic correlations useful for constructing the master sequence (ca $8 \mathrm{~m}$ ) from the twin cores.

Rock-Eval ${ }^{\circledR}$ pyrolysis analyses offer an estimation of total organic carbon (TOC, wt \%), mineral carbon (MINC, wt \%), hydrogen index (HI, in milligrams of hydrocarbons per gram TOC) and oxygen index (OI, in milligrams of hydrocarbons per gram TOC). These parameters were determined from 25 samples with a model 6 device (Vinci Technologies; [Espitalié et al., 1985a] and [Espitalié et al., 1985b]). The 25 samples document major 
lithologic changes. MINC estimates the carbonaceous fraction of sediments. The TOC indicates the organic matter (OM) abundance. HI and OI index depends on OM origin and on oxygen conditions, which determine OM degradation in the water column and sediments (Talbot and Livingstone, 1989; Meyers and Lallier-Vergès, 1999). High HI values could be associated with well-preserved algal OM source, whereas OI increase is mainly due to degraded OM contribution from autochthonous productivity and allochthonous inputs (Disnar et al., 2003; Magny et al., 2006; Millet et al., 2007). The petrographic study involved the microscopic examination of samples after acid hydrolysis of organic remains (the residual preparation is named: palynofacies). Their chromatic and textural characteristics allow the distinction of two groups: material of phytoplanktonic origin (Lallier-Vergès et al., 1993) and material from soils and vascular plants (Sifeddine et al., 1996).

\subsection{Pollen analyses}

Sampling resolution (samples in cubes of $1 \mathrm{~cm}^{3}$ and $1 \mathrm{~cm}$ thickness) on the whole sequence is 8 or $16 \mathrm{~cm}$. The sediment samples were treated chemically $(\mathrm{HCl}, \mathrm{KOH}, \mathrm{HF}$, acetolysis) and physically (0.5 mm sieving and decanting) following standard procedures (Moore et al., 1991). Lycopodium markers (Stockmarr, 1971) were added for estimation of pollen concentration (grains $/ \mathrm{cm}^{3}$ ). For identification of pollen types, we used keys (e.g. Moore et al., 1991; Beug, 2004) as well as the reference collection at the Institute of Plant Sciences in Bern. A total of 66 pollen samples were analysed under a microscope with a magnification of $400 \times$. For calculation of pollen percentages, pollen of water and wetland plants as well as spores of pteridophytes were excluded from the pollen sum. The total pollen sum is $>400$ grains. The pollen and charcoals diagrams were plotted with Tilia 2 (Grimm, 1992). Local pollen assemblage zones (LPAZ) were defined according to the zonation method of optimal partitioning (Birks and Gordon, 1985), as implemented in the program Zone version 1.2 (Juggins, 1991). The number of statistically significant zones was determined according to the Broken-stick model, as implemented in the program BSTICK (Bennett, 1996).

\subsection{Charcoal analyses}

Microscopic and macroscopic charcoal sedimentary concentrations were estimated from 66 and 801 samples, respectively. Microscopic charcoal particles $(>10 \mu \mathrm{m})$ mostly reflect regional fire history (e.g. MacDonald et al., 1991; Tinner et al., 1998; Carcaillet et al., 2001a; Gardner and Whitlock, 2001), whereas macroscopic particles $(>100-150 \mu \mathrm{m})$ express local (e.g. Clark, 1988; Whitlock and Millspaugh, 1996; Gavin et al., 2003b; Lynch et al., 2004; Higuera et al., 2005) as well as micro-regional fire episodes that may mainly depend on fire size and intensity (Pisaric, 2002; [Tinner et al., 2006a] and [Tinner et al., 2006b]; Peters and Higuera, 2007).

Microscopic charcoal was counted in the pollen slides with a light microscope at $250 \times$ magnification following Tinner and $\mathrm{Hu}$ (2003) and Finsinger and Tinner (2005); charcoal concentration $\left(\# / \mathrm{cm}^{3}\right)$ is calculated in proportion to the Lycopodium grains added to the samples. Influx values $\left(\# / \mathrm{cm}^{2} / \mathrm{yr}\right)$ derive from sedimentation accumulation rates (SAR) estimated with the age-depth model. For macroscopic charcoal quantification, data are based on the tallying of particles at $40 \times$ from contiguous $1-\mathrm{cm}$ sediment samples of $2 \mathrm{~cm}^{3}$ washed on a $150 \mu \mathrm{m}$ mesh sieve after acid and peroxide treatments (Rhodes, 1998; Gardner and Whitlock, 2001; Whitlock and Larsen, 2001; Whitlock and Anderson, 2003). Only macrocharcoal particles with well-preserved ligno-cellulosic structure with thin and elongated shape were counted, as they indicate a rapid transport to the lake during and immediately after the 
fire episodes (Vannière et al., 2003). As in the case of microscopic charcoal (Tinner and $\mathrm{Hu}$, 2003), counts of macroscopic charcoal particles usually give the same results as surface area estimation.

Charcoal counts for each sample were converted to macroscopic charcoal concentrations (CHAC) and then signal analysis was based on the decomposition method initially described by Long et al. (1998) and by use of the software CHARSTER v.0.8.3

(http://geography.uoregon.edu/gavin/software.html; by Daniel Gavin). The principal steps of the signal decomposition are the following. From the age-depth model the macroscopic charcoal raw data were re-sampled to interpolate them to a constant time interval. Then charcoal values were divided by the deposition time of the binned interval to obtain charcoal influx or charcoal accumulation rate $\left(\mathrm{CHAR} \# / \mathrm{cm}^{2} / \mathrm{yr}\right)$. To eliminate the slowly varying component or background signal of the charcoal record, influx values were smoothed with a robust locally weighted regression type (Lowess function) with a 500-yr time window that best fit the low frequency variation. Background charcoal influx (BCHAR) may be determined by several sedimentary processes on charcoal (e.g. the deposition of reworked particles from littoral sediment, Whitlock and Millspaugh, 1996). Alternatively, it may be also linked to fuel availability and characteristics (Vázquez et al., 2002; Marlon et al., 2006; Pausas and Bradstock, 2007) or regional fire activity (Whitlock and Larsen, 2001). However, the difference between charcoal influx and the background component defines the peak component (Clark et al., 1996; Lynch et al., 2003; Gavin et al., 2006). It is usually represented by two populations of values: the lowest ones are interpreted as analytical noise and the positive highest ones above the threshold values (TVs) are assumed to express fire episodes in the local or micro-regional area around the lake.

Two statistical distribution analyses were used to decompose the peak component and to choose the TV. First, sensitivity analysis allowed the identification of how the number of charcoal peaks varies with changing TV (Clark et al., 1996; Lynch et al., 2003). TV is in the range of values for which there is the lowest increase of residual peak number. Secondly, a Gaussian mixture model (Gavin et al., 2006; CHARSTER software) is used to analyse the histogram plot of the peak-component frequency distribution. This model helps to disentangle two overlapping subdistributions and to identify the upper limit of the main distribution, which may potentially be the upper limit of the analytical noise-related variation. The distribution of peaks along the sequence is evaluated by the smoothing sum of episodes in a defined moving time windows. IFF results from this time-series analysis of the peaks component (Long et al., 1998). The FRI and MFI are, respectively, estimated as the number of years between two episodes and between the first and the last fire episodes divided by the number of intervals between all the fire episodes.

\section{Results}

\subsection{Sedimentary data}

The age-depth model (Fig. 1d) indicates that the $8 \mathrm{~m}$ of sediments cover the last ca 11,700 years, with an average SAR of $0.7 \mathrm{~mm} / \mathrm{yr}$ (i.e. a time resolution per sample of $14.5 \mathrm{yr} / \mathrm{cm}$ ), spanning from a minimum of $0.4 \mathrm{~mm} / \mathrm{yr}$ to a maximum of $1.7 \mathrm{~mm} / \mathrm{yr}$ (or 25 and $6 \mathrm{yr} / \mathrm{cm}$ ). The 
average confidence interval of the error of the generalised mixed-effect regression model is ca $340 \mathrm{yr}$. Major variations in sediment GD are associated with basin-wide high-amplitude seismic reflectors (R1 to R7; Fig. 1c). Reflector R5 is characterised by an inclination different from that of R6 and R7. At the same depth, SAR calculated from the age-depth model increases and reaches its maximum (Fig. 2). This specific basin-fill geometry suggests that deep-water sedimentation was affected by lake-level fluctuations. The 25 TOC values plotted versus GD show a significant correlation (Fig. 3); GD increases with decreasing TOC, so we assume that GD reflects the minerogenic component, as it has been also observed at Lago di Mezzano (Sadori et al., 2004). Consequently, estimated TOC values have been calculated for the whole sequence (Fig. 2: estimated TOC). Qualitative observations of palynofacies show that most OM particles derive from lacustrine production, with a minor contribution of allochthonous inputs from the shore-belt vegetation or soil OM. High TOC and HI values with low OI values indicate the accumulation of well-preserved autochthonous OM, while inverse OM characteristics involve high processes of OM degradation in well-oxygenated environments.

According to GD and Rock-Eval measurements, nine main sedimentary facies (MSF) describe this laminated organic and calcareous sequence (Fig. 2). MSF1 record spans ca 1500 years between ca 11,700 and 10,200 cal. yr BP; and the GD values are low and TOC percentage relatively high. Carbonate versus organic fine laminations may represent an annual signal. Several successive GD peaks record a sub-phase at 750-780 cm depth, i.e. ca 11,10011,400 cal. yr BP. Increase of MINC percentages and decrease of TOC percentage characterise MSF2 (10,200-6300 cal. yr BP). OI values are up to $400 \mathrm{mg} \mathrm{CO} / \mathrm{g}$ TOC. This tendency is briefly interrupted between 630 and $600 \mathrm{~cm}$ depth as shown by GD values. Compared with MSF1, the coarse laminations and sediments properties imply an important change in environmental conditions, as shown by the loss of the annual signal indicating more oxygenated water. MSF3 sediments conserve high GD values and associated low TOC percentages, but with weak variation in the carbonaceous fraction. At level $367 \mathrm{~cm}$ the highest SAR corresponds with the lowest $\mathrm{HI}$ value and an OI of ca $260 \mathrm{mg} \mathrm{CO}_{2} / \mathrm{g}$ TOC. This marks an allochthonous contribution of $\mathrm{OM}$ as well as silicate material. The abrupt change in the MINC and HI curves above $295 \mathrm{~cm}$ depth and after $4500 \mathrm{cal}$. yr BP (MSF4) implies an evolution towards well-oxygenated water, an algal contribution to OM sedimentation, high OM degradation processes, and carbonate precipitation on the littoral platform in a context of a high lake level.

The sharp transition MSF4-MSF5 (240 cm; R4) documents a rapid evolution of lacustrine sedimentation and of the whole ecosystem at ca 3600 cal. yr BP. Granulometry increases, with more sand (Matter, 2005). Seismic data, along with the drop in GD and MINC values and the increase in TOC percentage reflect a lower lake-level, probably associated with allochthonous OM and silicate inputs. The finely laminated MSF6 sediments successively records alternating carbonaceous sedimentation, decrease of OM contribution, and $\mathrm{IH}$ increase and then decrease. The coarsely laminated MSF7 sediments parallel the GD curve and to the increase in MINC and OI values, which reflect the low contribution of highly degraded OM to sedimentation. The thin MSF8 section identified on the seismic profile between the high-amplitude reflectors R1 and R2 and by abrupt GD curve inflections is characterised by increased phytoplanktonic OM accumulation as well as coarse calcareous concretions visible to the naked eye, which contribute considerably to the GD decrease. Clay deposits in the top sequence (MSF9) are clearly marked by allochthonous OM inputs which suggest strong erosion on the watershed. 


\subsection{Pollen-inferred vegetation history and corresponding (low-resolution) microscopic and macroscopic charcoal data}

In total, 66 pairs of pollen and microscopic charcoal samples at every 8 or $16 \mathrm{~cm}$ cover the whole sequence (Fig. 4, for more details see Colombaroli, 2007; Colombaroli et al., in press). Influx and pollen percentages have similar trends, so we present and discuss only the percentage values. Pinus, Q. ilex-type (t.), Quercus pubescens-t., Corylus, and Ericaceae are important pollen types in this Holocene sequence. The pollen record is subdivided into six statistically significant LPAZ. Interestingly, except for a few samples, the trend of microscopic and macroscopic charcoal curves are similar, and charcoal influx values are similar to the concentration values. Only around 350-400 and 580-630 cm depth, respectively, do minimum and maximum SAR values lead to modified charcoal input signals.

The diagram shows a first phase with a progressive decrease of herb pollen (LPAZ AC05-1; $11,700-10,400$ cal. yr BP; from $60 \%$ to $20 \%$ ), indicating an open landscape that developed into rather closed forests during this period. Pinus and Q. pubescens-t. pollen values reach $15 \%$ and $40 \%$, respectively. Both microscopic and macroscopic charcoal influxes are at their maximum. Subsequently, the sequence is characterised by alternating phases with dominances of pollen of deciduous oaks (LPAZ AC05-2; AC05-4, and AC05-6) and pollen of evergreen oaks (AC05-3 and AC05-5), suggesting rather drastic shifts between evergreen and deciduous forest types.

During LPAZ AC05-2 (10,400-8600 cal. yr BP) values of tree pollen (mainly Q. pubescenst.) are relatively stable around $80 \%$, documenting the prevalence of deciduous forests. Charcoal influx decreases through the zone. High peaks in microscopic and macroscopic charcoal at the end of the zone are synchronous with an increase of pollen of shrubs and a decline of pollen of trees, suggesting a fire-linked transformation of the forested environments.

LPAZ AC05-3 (8600-7900 cal. BP) is characterised by the nearly instantaneous increase of pollen of $Q$. ilex-t., indicating the expansion of evergreen forests in the Accesa area. The subsequent decline of pollen percentages of Q. ilex-t. (from 60\% to 30\%; LPAZ AC05-4) is dated at ca 7900-7700 cal. yr BP and occurred together with an increase of pollen of herbs (Colombaroli et al., in press). Microscopic and macroscopic charcoal influx increase, suggesting that the decline of evergreen oak forests was associated with an increase of charcoal influx and thus of fire activity. In general, this pollen zone is characterised by relatively high non-arboreal pollen values (e.g. Poaceae) documenting rather open forested environments.

During LPAZ AC05-5 (6200-2800 cal. yr BP), tree pollen (mainly Q. ilex-t.) recovers (up to $80 \%$ ), indicating the re-establishment of rather closed forests. Microscopic and macroscopic charcoal particles show different trends, with a pronounced minimum in the macroscopic charcoal and a peak at around $5000 \mathrm{cal}$. BP recorded only in the microscopic concentration and influx series. The increase of $Q$. ilex-t. pollen, however, is closely related to minimum charcoal values in both the microscopic and macroscopic series, again suggesting low fire activity when evergreen forests expanded. Towards the end of the zone AC05-5 (ca 3500 cal. yr BP), pollen percentages of Q. pubescens-t. slightly increase, whereas $Q$. ilex-t. decreases markedly (from $50 \%$ to $20 \%$ ) together with pollen of all tree taxa. Again this shift from evergreen to deciduous vegetation is associated with an increase of charcoal influx and thus fire incidence. 
After a break, the vegetational shift continues in LPAZ AC05-6 (from 2800 cal. yr BP), where pollen percentages of $Q$. pubescens-t. reach $50 \%$, while pollen percentages of $Q$. ilex-t. become less than 10\%. Pollen of Poaceae and Corylus decreases as well. Towards the end of zone AC05-6 pollen of all tree taxa declines with two major minima at around 1300 and 400 cal. BP (respectively, tree pollen reaches ca $50 \%$ and $35 \%$ ). The first decline of tree pollen coincides with a maximum of macroscopic charcoal influx, while the second is synchronous with a peak in microscopic charcoal influx. Pollen (e.g. Artemisia, Plantago) and charcoal data suggest that during this last phase the landscape around the lake became more open, with large areas opened for agricultural purposes in part by the use of fire.

\subsection{Macroscopic charcoal inferred fire frequency}

Minimum and maximum macroscopic charcoal concentrations are 0.505 and $513.131 \mathrm{\#} / \mathrm{cm}^{3}$, respectively, which, taking into account SAR, leads to minimum and maximum influx values (CHAR) of 0.036 and $46.684 \mathrm{\#} / \mathrm{cm}^{2} / \mathrm{yr}$. These values are similar to those from other coastal records from south-eastern Italy (Caroli and Caldara, 2006), eastern Australia (Mooney and Maltby, 2006), and the western USA (Long and Whitlock, 2002). They are higher than CHAR measured in lake or mire sediments from north latitude Mountains for instance from the Swiss Alps (Stähli et al., 2006), from the Rocky Mountains (USA; Brunelle et al., 2005), or from Alaska (Lynch et al., 2003). For the estimation of the background component (BCHAR) or CHAR tendency (see Section 3.5.) the re-sampling bin-width chosen was $25 \mathrm{yr}$ and corresponded to the lowest SAR in the whole sequence (Fig. 5). BCHAR reached maximum values between 11,600 and 10,200 cal. yr BP, with a short period of decrease around 11,200 cal. yr BP. Then, with a progressive decrease, it reached low values at ca 9200 cal. yr BP and remained stable until 8000 cal. yr BP. Between 8000 and 5000 cal. yr BP BCHAR values are somewhat higher, with progressively lower maxima at ca 7400,6900 6500, and 5700-5400 cal. yr BP. Microcoscopic charcoal particle influx clearly follows these oscillations (Fig. 5). During the second half of the Holocene BCHAR shows three phases with increased values around 3600-3100, 2600-2400, and 1500-1100 cal. yr BP. For this period microscopic charcoal influx remains very low, i.e. less than or around $10,000 \# / \mathrm{cm}^{2} / \mathrm{yr}$, except for the peak at ca 500 cal. yr BP.

The frequency-distribution analysis of residual peak values (difference between CHAR and BCHAR) with a Gaussian mixture model allows us to identify two clusters (Fig. 6). On the basis of the sensitivity analysis (as illustrated by the distribution curve of negative and positive residual peaks and the cumulative number of retained peaks under varying TVs) a TV of $0.7 \# / \mathrm{cm}^{2} / \mathrm{yr}$ was selected. Seventy-five residual peaks are identified above this TV and are interpreted as local (to regional) fire episodes. We use the fire episodes to estimate the IFF per 500 and 1000 years (Fig. 5). For instance, over the entire sequence IFF varies between 1.1 and 6.2 episodes $/ 500 \mathrm{yr}$. MFI for the entire Holocene is $152 \mathrm{yr}$ and on an average oscillates between 80 and $450 \mathrm{yr}$. FRI reaches a minimum of $50 \mathrm{yr}$ and a maximum of $525 \mathrm{yr}$ (Fig. 7). In the whole sequence, eight significant MFI increases could be identified at ca 11,500$10,500,9650-9450,9000-8450,8000-7400,6500-5750,5500-5100,3600-3100$, and 2000$1200 \mathrm{cal}$. yr BP. Two maxima up to $450 \mathrm{yr}$ are recorded in FRI at ca 8100 and 4000 cal. yr BP.

We also applied other techniques to estimate BCHAR and thus the residual peak component. For instance, we used different time windows for Lowess smoothing $(300,800)$ and log transformation of CHAR values. To identify charcoal episodes we also tried the ratio CHAR/BCHAR, and higher TVs (Clark et al., 1996; Long et al., 1998; Lynch et al., 2003; 
Gavin et al., 2006; Marlon et al., 2006). The distribution of peaks always followed the same trend, but with lower total peak numbers (ca 35-50) that would result in rather long periods (1000-2000 yr) without any fire episode. However, residual peaks concentrate on three periods with many identified charcoal peaks between 9500 and 8000 cal. yr BP, a few spaced peaks between 6000 and $4000 \mathrm{cal}$. yr BP, and again many after $3800 \mathrm{cal}$. yr BP. Thus, by using these alternative (and more conservative) approaches, the MFI for the whole Holocene is significantly longer, with values of ca 230-320 yr (instead of $152 \mathrm{yr}$ ).

\section{Discussion}

\subsection{Estimation of fire frequency and fire return interval}

Quantification of fire signals by (sieved) macroscopic and (pollen-slide) microscopic charcoal display similar trends before 6000 cal. yr BP (Fig. 4), although some discrepancies appear in the signal amplitude around and after 8000 cal. yr BP. Differences in the spatial pattern of fire or taphonomic and sedimentary processes could be at the origin of these discrepancies. For instance, Carcaillet et al. (2001a) suggest that these differences could result from the regional source of small particles and/or high fragmentation during pollen-type chemical treatment. In contrast, quantitative comparisons between thin-section and pollen-slide charcoal series of the same core yielded no evidence of fragmentation during standard pollen procedures (Tinner et al., 1998; Tinner and $\mathrm{Hu}, 2003)$. Instead, statistical analyses of particle-size distributions (Tinner and $\mathrm{Hu}, 2003)$ showed that large particles $(>0.2 \mathrm{~mm})$ are eliminated by the pollenslide method, which involves highly selective physical procedures such as sieving and decanting of sediments.

Unfortunately, the absence of historical fire data or studies of tree-ring scars from Lago dell'Accesa region raises some difficulties in the estimation of the TV by which a charcoal peak is identified as a local fire event (Gavin et al., 2003b; Lynch et al., 2004; Higuera et al., 2005). The major peaks detected would reflect the local space/time dynamics of fire (Fig. 5). The estimated MFI of ca $152 \mathrm{yr}$ is in accordance with the study of Arora and Boer (2005), which simulated a FRI of $153 \mathrm{yr}$ under quasi-natural conditions for the southern plain of Spain, and with modern data from Greece (100-150 yr, Hadjibiros, 2001). Shorter fire-return intervals have been estimated from recent observation for northern mountains and wetter places in Spain (Vázquez et al., 2002), where higher lightning frequency would favour fire ignitions (Arora and Boer, 2005). Combining modern observations and historical data, Moreno (1998) suggested a mean fire-return interval for Italy of ca $53 \mathrm{yr}$ for the period 19801990. Even so, there is a high variability in Mediterranean countries ( $40 \mathrm{yr}$ to even $2000 \mathrm{yr}$ ) related to the degree of land fragmentation and land-use. For the past 25 years, many scientists have agreed that fire frequency has increased (Moreno, 1998; Pausas and Vallejo, 1999; UNECE-FAO Report, 2002; Pausas, 2004; UNECE ICP-BFH Executive Report, 2004). The long-term fire-history study at Accesa shows that MFI could have reached an average of $80 \mathrm{yr}$ during high fire-frequency periods, with two episodes separated only by ca $50 \mathrm{yr}$ (Fig. 7). These results are comparable with the present-day variability observed in European Mediterranean countries and are linked with spatial landscape diversity (Moreno, 1998). Independent of ecological changes for the Holocene, the long-term MFI average of $152 \mathrm{yr}$ appears closer to the assumed quasi-natural fire regime. The frequencies observed by these historical and modern ecological studies are in good agreement with the palaeo-IFF and MFI results. We thus conclude that the approaches used in this study are able to document important parameters of past Mediterranean fire regimes. 


\subsection{Early Holocene fire regime and climate seasonality}

During the earliest Holocene (ca 11,700-10,500 cal. yr BP), our CHAR record suggests a high IFF, when the tree vegetation cover was rather open and lake-levels lowered twice (Fig. 7 and Fig. 5b). Dry climatic conditions during the summer (Rossignol-Strick, 1999; DrescherSchneider et al., 2007) could have induced lower lake-levels as well as higher fire frequencies. In agreement, it has been suggested that high seasonality, summer drought, and frequent fires favoured the expansion of Corylus in northern Italy (Finsinger et al., 2006) and elsewhere in Europe (e.g. Huntley, 1993; Tinner and Lotter, 2001). High-amplitude fluctuations of reconstructed annual sea-surface temperatures support this evidence for stronger seasonality in the North Atlantic realm during the early Holocene (de Vernal and Hillaire Marcel, 2006). High seasonality during the early Holocene was probably a consequence of orbital parameters, inducing a minimum of winter solar radiation and a maximum of summer solar radiation in the Northern Hemisphere at ca 9 ka (Kutzbach and Webb, 1993). Such climatic conditions could explain the occurrence of laminated sediments at Lago dell'Accesa and could have advantaged fires, since dry summer conditions favour fire ignition and expansion. In agreement, charcoal series from around the Mediterranean basin in Sicily (Lago di Pergusa, Sadori and Giardini, 2006), Spain (Lake Siles; Carrión, 2002), and Turkey (Lake Van; Wick et al., 2003) also show high charcoal values during the early Holocene that were attributed to frequent fires. Similar results were obtained on the west coast of North America (Millspaugh et al., 2000; Gavin et al., 2003a; Whitlock et al., 2003; Whitlock et al., 2007; Anderson et al., 2008). These paleoecological findings are in agreement with modern observations from Liguria in northern Italy (Telesca et al., 2007) which reveal a high variability in the spatial distribution of forest fires (1997-2003) with largest fires (surface extension $>400$ ha) reflecting a cyclic pattern connected with seasonality.

Magny et al. (2006) deduced from their lake-level study that warmer climatic conditions, probably resulting from the restoration of the thermohaline circulation (Björck et al., 1996) and an orbitally induced summer-insolation maximum, led to an intensification of the hydrological cycle over the western Mediterranean area. The low lake level dated to ca 11,350-11,150 cal. yr BP and associated with a high IFF period is synchronous with relative sedimentary changes in core AC05-B (Fig. 2). Magny et al. (2006) associated this phase, which is accompanied by a slight decrease in tree pollen, with the Preboreal Oscillation (see Björck et al., 1997; Sangiorgi et al., 2002; Cacho et al., 2006). Both the pollen data from the central lake (this study) and littoral cores (Drescher-Schneider et al., 2007) record an expansion of deciduous thermophilous trees at ca 11,000 cal. yr BP. Later on, between 10,500 and 9000 cal. yr BP, lower IFF occurred in forested environments dominated by deciduous Quercus during a period with relatively high lake levels.

A drop in lake levels is recorded at 9000 cal. BP, when deciduous oaks started to decline and IFF increased, probably as a result of drier conditions in this part of the Mediterranean region (Magny et al., 2006). This period with drier conditions, more frequent fires, and lower lake levels spanned ca $500 \mathrm{yr}$ and ended at ca 8500-8300 cal. yr BP. Chronologically, this period corresponds to the Sapropel 1 deposits and is synchronous with increased Nile River floods and possibly more humid conditions in the eastern Mediterranean (Ariztegui et al., 2000). This reconstruction is supported by stalagmite data from Corchia cave (northern Italy) that suggest increased of precipitation in the western Mediterranean during the deposition of Sapropel 1 (Zanchetta et al., 2007). Charcoal data available from Lago di Pergusa in upland Sicily (Sadori and Giardini, 2006) and from Lake Van in Turkey (Wick et al., 2003) also attest to high CHAR until 8400/8200 cal. yr BP. But the authors interpret pollen data from the 
same series as the indices of wet climatic conditions. In contrast, rather dry climatic conditions during the early Holocene at around 8400/8200 cal. BP are recorded in southern Spain (Reed et al., 2001). These differences may have resulted from the regional climatic setting. However, we have to take in account the relative sensibility of the different proxies and/or seasonality of climate (Carcaillet et al., 2001b; Wick et al., 2003; Magny et al., 2007). Actually, the fire-frequency and lake-level records are more sensitive to summer conditions (Magny, 1998). Wick et al. (2003) proposed that during the first part of the Holocene moisture increase was synchronous with dry spring-summer weather in Anatolia. Zanchetta et al. (2007) suggested that the precipitation increase observed at Corchia cave (central Italy) resulted from NAO oscillations that influenced winter-season rainfall.

\subsection{Holocene fire regime, hydrological patterns, and ecological change}

The Holocene expansion of Q. ilex forests started at about 8600 cal. yr BP, peaked at 8400 7900 cal. yr BP, and ended at about 7600 cal. yr BP. Q. ilex is a drought-adapted species with a high sensitivity to frost (Pigott and Pigott, 1993; Conedera and Tinner, 2000; Grund et al., 2005). Low lake-levels before 8300 cal. yr BP and high lake levels at around 83008100 cal. yr BP, however, indicate that this period was probably characterised by heterogeneous climatic conditions, most likely including changes in the precipitation regime. Transient humidity increases during this period are also suggested by high percentages of Abies and Fagus pollen (Drescher-Schneider et al., 2007; Colombaroli et al., in press). Dry (summer) climatic conditions, which prevailed between 9100/8400 and 8100/7700 cal. yr BP, possibly favoured fire ignition. Lake-level changes suggest that this situation was interrupted by a short humid period of 300-400 yr that resulted into less fire activity according to IFF and FRI estimations. Interestingly, during this period Q. ilex continued to expand. We therefore hypothesise that climatic changes (i.e. less dry conditions) would be enough to be recorded by lake-level and MFI increase but would be also moderated enough to maintain the $Q$. Ilex-t stands that had expanded during a dry period already at 8700-8600 cal. BP. Thus, it is conceivable that high FRI and low FFI could have directly advantaged evergreen oaks even during a relatively less dry period. The temporary lake-level changes and the low fire incidence fall into the range of the $8.2 \mathrm{kyr}$ cal. BP cold event and could be the geo-ecological consequence of this global climatic event (Wick and Tinner, 1997; Tinner and Lotter, 2001; [Magny et al., 2003] and [Magny et al., 2006]; Alley and Agustsdottir, 2005).

After ca 8000 cal. yr BP (Fig. 4 and Fig. 5) IFF increased while lake-levels reached very low stands (Magny et al., 2006), indicating that climate was again drier. For this (lake-levelinferred) dry period, time-series analyses from Lago dell'Accesa and Lago di Massaciuccoli (also in Tuscany) suggest that increasing fire frequency considerably reduced the abundance of Q. ilex (Colombaroli, 2007; [Colombaroli et al., 2007] and [Colombaroli et al., in press]). The little gap between maximum IFF and the lake-level drop may result from chronological uncertainties in both Accesa records (central and littoral sequences). Indeed, the central and littoral Q. ilex expansions and declines show a difference of about $400 \mathrm{yr}$ (Magny et al., 2006; Drescher-Schneider et al., 2007). However, the littoral record clearly shows that the peak of evergreen oak (but not the onset of the expansion) is synchronous with the low lake level. The increase in charcoal influx is also recorded in the littoral sequence just after the $8.2 \mathrm{kyr}$ deposit of lake marl (Magny et al., 2006).

During the $Q$. ilex expansion and dominance, the forests were relatively closed. Instead, between 7900 and 7700 and 6500 cal. yr BP, deciduous Quercus (probably Q. pubescens, see Drescher-Schneider et al., 2007) increased and shrub and herbs were more abundant 
(Colombaroli, 2007; Colombaroli et al., in press). This change was associated with a significant increase of microscopic charcoal suggesting increased fire activities in the Accesa region. The situation appears more complex when consulting reconstructed local IFF (Fig. 7 and Fig. 5b), with a strong increase between ca 7900 and 7400 cal. yr BP, a subsequent minimum of IFF at 7200-6600 cal. yr BP, and finally a re-increase at $6500 \mathrm{cal}$. BP. Around 7700 cal. yr BP, lake-level rises at Lago dell'Accesa (Magny et al., 2007) suggest more humid conditions. However, it is likely that at least some of the fires were of anthropogenic origin. High-resolution pollen and charcoal series (contiguous analyses of every cm between 8400 and 6400 cal. yr BP, see Colombaroli, 2007; Colombaroli et al., in press) on the central lake cores suggest that increases of regional and local fire frequencies after $8000 \mathrm{cal}$. BP were at least partially connected to Neolithic agricultural activities around the lake at ca 7900$7700 \mathrm{cal}$. BP. This interpretation is mainly based on the close link between pollen indicative of agriculture (e.g. Plantago lanceolata, Artemisia) and the microscopic and macroscopic charcoal records. This more humid phase may correspond to the Central European cool-humid phase CE-4 (or "Frosnitz" in the Austrian literature), which lasted from 7500 to 7100 cal. yr BP (e.g. Haas et al., 1998; Nicolussi and Patzelt, 2000). Similar to the conditions at Accesa, a climatic shift to more humid conditions at ca $7000 \mathrm{cal}$. yr BP has been recorded in the south-western Mediterranean (Reed et al., 2001; Carrión, 2002). However, the period of lower IFF is relatively long (7200-6600 cal. yr BP, ca $600 \mathrm{yr}$ ) and is followed by a new phase of frequent fires. A more or less corresponding trend is recorded in lake-level change with a drop around $6400 \mathrm{cal}$. yr BP, when fire frequency increased. In agreement, a peat layer indicating a low lake-level is recorded at Lago di Mezzano ca 6700-6400 cal. yr BP (Ramrath et al., 2000). Q. ilex, however, as in the preceding periods, increases only significantly when fire frequency declines again at ca $5800 \mathrm{cal}$. yr BP. This close link between fire incidence and $Q$. ilex abundances continues during the next centuries with an IFF increase and a synchronous decline of $Q$. ilex around 5300 cal. yr BP and again a decrease of IFF and an expansion of Q. ilex at ca 4300 cal. yr BP. In agreement, recent paleoecological studies at nearby Lago di Massaciuccoli suggest that (late-successional) forests of $Q$. ilex are easily disrupted by fires and are usually replaced by macchia vegetation. This high fire sensitivity of mature Q. ilex stands has also been found at Croatian sites and in Sicily (Colombaroli, 2007).

\subsection{Holocene fire regime and human impact}

As pointed out above, pollen data from Lago dell'Accesa suggest that the decline of Q. ilex and the IFF increase between 8000 and $7600 \mathrm{cal}$. yr BP were synchronous with an increase of plants indicative of human activities, such as $P$. lanceolata, Rumex acetosella, Cichorioideae, Chenopodiaceae, Apium, Artemisia, and Pteridium (Drescher-Schneider et al., 2007;

Colombaroli et al., in press). These taxa are often related to open habitats used for agricultural practices (Behre, 1981) and increase further around 4500-3800 cal. yr BP and during the Etruscan and Roman periods (Drescher-Schneider et al., 2007). In the central lake core these taxa are abundant already during the period 7700-6000 cal. yr BP (Fig. 4; for further details see Drescher-Schneider et al., 2007; Colombaroli et al., in press). The beginning of the Neolithic culture is only documented in Tuscany by occasional discoveries of Cardial pottery (from 8000 cal. yr BP; Malone, 2003). The middle Neolithic (ca 7500-5300 cal. yr BP) is attested by the excavated site of Piensa (Malone, 2003). But it is the late Neolithic (ca 53004500 cal. yr BP) that is probably the best represented in the region by cave settlements (e.g. around Pisa and Siena; Settis, 1985). During this period farming economies became more intensive. The use of fire in European Neolithic cultures for land-use and clearance is widely attested (Clark et al., 1989; Carcaillet, 1998; Tinner et al., 1999; Vannière and Martineau, 2005). Tinner et al. (2005) reported charcoal increases in lacustrine sedimentary sequences on 
the Swiss plateau at ca 6200 and 5500 cal. yr BP. They coincided with declines of pollen of fire-sensitive tree taxa at both sites. At the same time, higher fire activity is recorded at Lago di Massaciuccoli in northern Tuscany (Colombaroli et al., 2007; Fig. 8). It thus appears clear that besides climate, human impact was a driver of changes in both vegetational and fire regime for this period (8000-6000 cal. yr BP). The rather close link between lake levels and IFF (e.g. high lake stands and low IFF at 4800 and 4300) suggests that increased moisture availability diminished fire susceptibility of the ecosystems, probably favouring natural and anthropogenic ignition. However, similar findings (high lake levels before ca 4000 cal. yr BP) corroborate the lake-level-inferred climatic trends at other Italian sites (Giraudi, 1998; Sadori et al., 2004 L. Sadori, C. Giraudi, P. Petitti and A. Ramrath, Human impact at Lago di Mezzano (central Italy) during the Bronze Age: a multidisciplinary approach, Quaternary International 113 (2004), pp. 5-17.

For the Bronze Age, ca 4000-2900 cal. yr BP, no local settlement is known around the Lago dell'Accesa (Camporeale and Giuntoli, 2000). Nevertheless, human presence and land-use is attested by pollen. Around 3800-3600 cal. yr BP, lake levels were rather low (Fig. 5), and IFF increased toward maximum values at 3700-3200 cal. yr BP. Sedimentological analyses show that terrigenous inputs indicate erosion in the watershed. Environmental changes around the lake appear particularly marked. Increases in fire and erosion processes connected to drier climate and/or human impact are reported from other Italian sites (Caroli and Caldara, 2006; Sadori and Giardini, 2006; Fig. 8). It is likely that human populations increased during the Bronze Age and that land-use was more intensive. In agreement, human influences on sedimentation processes are also recorded in the Adriatic region during this period (3800 cal. yr BP; Oldfield et al., 2003; Rolph et al., 2004). However, the first important settlement around Lago dell'Accesa occurred during the Villanova culture (2900$2700 \mathrm{cal}$. BP; first Etruscan period). Tombs and houses belonging to miners testify to an occupation of the territory that spans from ca 2800 (tombs)-2600 (houses) to 2500 cal. yr BP (Camporeale, 2000; Camporeale and Giuntoli, 2000; Lobell, 2002). A slight IFF increase is contemporaneous with this nearby occupation (Fig. 7), when the lake level was rather high. After 1000 cal. yr BP only three peaks are recorded in the macroscopic charcoal series. Sediments were rich in rounded microscopic charcoal particles, which are most likely reworked from soils and mark strong erosional processes. Erosion was probably linked with agricultural activities that implemented another use of fire than before. This is in agreement with pollen data suggesting that most parts of the area where open and used as crop fields or pastures which were probably susceptible to erosion. Considering the available records, periods with increased fire activity were coarsely synchronous in Italy during the late Holocene (Fig. 8). Taken together, it is likely, that human activities contributed to increased fire frequencies during this period of demographic increase.

\subsection{Climate versus human-driven Holocene fire regimes}

Statistical analysis of the period 1997-2003 in Tuscany shows that the fire regime was determined by climate-related periodicities (Telesca and Lasaponara, 2006), though it is clear that in the Mediterranean region most fires are initiated by human activities (Moreno, 1998). Generally models show a large influence of climate and weather on landscape-fire-succession, although terrain complexity and fuel patterns are also relevant (Rollins et al., 2002; Cary et al., 2006). The importance of the precipitation regime on extreme fire occurrences is undoubted (Pausas, 2004; Trouet et al., 2006; Pausas and Bradstock, 2007), even in the modern humanised landscape. Fig. 9 presents a synthesis of millennial fire frequencies compared with lake-level trends. During the first part of the Holocene $(11,700-$ ca 
4000 cal. yr BP), the amplitude and rhythms of hydrological and fire regimes followed the same trend in millennial scales. During the second part of the Holocene (after ca 4000 cal. yr BP), the amplitude of IFF changes was always higher than that of the lake-level ones and was most likely related to interferences with human impact (e.g. slash-and-burn agriculture, animal husbandry, and mine exploitation), even if climate influence on fire regime was still significant. Similar results showing a close link between Holocene climatic changes, land-use, and the fire regime were obtained in Italian Switzerland (Tinner et al., 1999) and in Spain (Carrión, 2002; [Carrión et al., 2003] and [Carrión et al., 2007]). Unambiguous evidence also shows that fire was a natural component of ecosystems throughout the Holocene in the dry and continental Swiss central Alps (e.g. with MFI of $250 \mathrm{yr}$ in mountain-pine forests; Stähli et al., 2006).

However, in the temperate biome of central Europe and most regions of the Alps, fire incidence has been principally attributed to human activities. Before the Neolithic fire frequencies were very low (Carcaillet, 1998; [Tinner et al., 1999] and [Tinner et al., 2005]; Carcaillet et al., 2002; Gobet et al., 2003). It is also the same for Spain's Mountainous area ([Carrión et al., 2003] and [Carrión et al., 2007]). Our new charcoal records show that this was different in the fire-prone Mediterranean ecosystems around Lago dell'Accesa, where fire frequency was rather high during the entire Holocene with MFI between ca $450 \mathrm{yr}$, and less than $100 \mathrm{yr}$, with an average of $150 \mathrm{yr}$ for the entire Holocene. During LPAZ AC05-1 and 2 MFI are, respectively, 130 and $158 \mathrm{yr}$, whereas MFI became longer (300 yr) during the period of Q. ilex dominance (LPAZ AC05-3). During the post-Neolithic periods, LPAZ AC05-4, 5 and 6, MFI reaches values close to the early Holocene ones of 131, 154, and $187 \mathrm{yr}$, respectively. Because of the high incidence of fire before the onset of the Neolithic, our results imply that fire can be considered an important natural component of Mediterranean ecosystems. This natural-fire component must be clearly separated from destructive anthropogenic fires that partly resulted in marked vegetational and environmental changes, such as the replacement of former $Q$. ilex forests by macchia shrubland.

\section{Conclusion}

This paper presents a continuous record of fire-regime changes for the last $11,700 \mathrm{yr}$ from Lago dell'Accesa in Tuscany (Italy). The combined evaluation of charcoal-inferred fire regimes with hydrological, vegetational, and archaeological data reveals strong relationships among climate, fire, vegetation, and land-use and attests to the paramount importance of fire in Mediterranean ecosystems. The main findings are:

(1) The MFI for the entire Holocene was estimated to be $150 \mathrm{yr}$, with a minimum around $80 \mathrm{yr}$ and a maximum around $450 \mathrm{yr}$. One hundred and fifty years could represent the quasinatural MFI in Mediterranean ecosystem. The frequencies observed by historical and modern ecological studies are in good agreement with the palaeo-MFI results.

(2) The periods of maximum local fire activity are dated around 11,300, 10,700, 9500, 8700, $7600,6200,5300,3400,1800$, and 1350 cal. yr BP.

(3) The macro-charcoal record suggests that before 4000 cal. yr BP, longer or shorter fire rotation intervals are principally related to hydroclimatic variations. Fire-activity maxima reflect drier climatic periods. 
(4) At the beginning of the Holocene high climate seasonality favoured fire expansion in this region, as in many other ecosystems of the northern and southern hemispheres.

(5) Since the onset of Neolithic land-use at ca 8000 cal. yr BP humans have undoubtedly affected the fire regime, leading to higher fire frequencies. The use of fire as a tool was intensified during the Bronze Age (4000-3800 cal. yr BP), when the fire regime was clearly related to both climatic conditions and human activities.

(6) Charcoal-pollen time-series analyses clearly indicate that anthropogenically enhanced fire disturbance strongly promoted the establishment of shrublands and macchia in the Mediterranean area, particularly at the expense of the previously widespread Q. ilex forests.

(7) The anthropogenic phases with maximum fire activity corresponded to greater sensitivity of the vegetation and triggered changes in vegetational communities (e.g. decline of Q. ilex forests).

\section{Acknowledgements}

The authors are grateful to Jacques-Louis de Beaulieu, Robert Hoffmann, Cecile Matter, Willi Tanner, Elisa Vescovi for their help during the coring in 2005. We would also like to thank Agnès Stock and Julien Didier from Besançon University for laboratory help and Cecile Matter, Michael Strasser and Stéphanie Girardclos from ETH Zurich for their contribution to the seismic survey and geophysics analyses. We also acknowledge Herb Wright for English language corrections, R. Scott Anderson and one anonymous reviewer provided constructive suggestions. This study was financially supported by the French CNRS (National Centre for Scientific Research) within the framework of the ECLIPSE program (Past Environment and Climate) and by the Swiss National Science Foundation (Project number 3100A0-102272).

\section{References}

Alley and Agustsdottir, 2005 R.B. Alley and A.M. Agustsdottir, The 8k event: cause and consequences of a major Holocene abrupt climate change, Quaternary Science Reviews 24 (2005), pp. 1123-1149

Anderson et al., 2008 R.S. Anderson, C.D. Allen, J.L. Toney, R.B. Jass and A.N. Bair, Holocene vegetation \& forest fire regimes in subalpine \& mixed conifer forests, southern Rocky Mountains, USA, International Journal of Wildland Fire 17 (2008), pp. 96-114.

Ariztegui et al., 2000 D. Ariztegui, A. Asioli, J.J. Lowe, F. Trincardi, L. Vigliotti, F. Tamburini, C. Chondrogianni, C.A. Accorsi, M. Bandini Mazzanti, A.M. Mercuri, S. Van der Kaars, J.A. McKenzie and F. Oldfield, Palaeoclimate and the formation of sapropel S1: inferences from Late Quaternary lacustrine and marine sequences in the central Mediterranean region, Palaeogeography, Palaeoclimatology, Palaeoecology 158 (3-4) (2000), pp. 215-240

Arora and Boer, 2005 V.K. Arora and G.J. Boer, Fire as an interactive component of dynamic vegetation models, Journal of Geophysical Research Biogeosciences 110 (2005), pp. 58-77.

Baeza et al., 2007 M.J. Baeza, A. Valdecantos, J.A. Alloza and V.R. Vallejo, Human disturbance and environmental factors as drivers of long-term post-fire regeneration patterns in Mediterranean forests, Journal of Vegetation Science 18 (2007), pp. 243-252. 
Behre, 1981 K.-E. Behre, The interpretation of anthropogenic indicators in pollen diagrams, Pollen et Spores 23 (1981), pp. 225-245.

Bennett, 1996 K.D. Bennett, Determination of the number of zones in a biostratigraphical sequence, New Phytologist 132 (1996), pp. 155-170.

Bergeron and Archambault, 1993 Y. Bergeron and S. Archambault, Decreasing frequency of forest fires in the southern boreal zone of Québec and its relation to global warming since the end of the Little Ice Age, The Holocene 3 (1993), pp. 255-259.

Beug, 2004 H.J. Beug, Leitfaden der Pollenbestimmung für Mitteleuropa und angrenzende Gebiete, Verlag Dr. Friedrich Pfeil, München (2004).

Birks, 1997 H.J.B. Birks, Reconstructing environmental impacts of fire from the Holocene sedimentary record. In: J.S. Clark, H. Cachier, J.G. Goldammer and B.J. Stocks, Editors, Sediment Records of Biomass Burning and Global Change. NATO ASI Series I, Springer, Berlin (1997), pp. 295-311.

Birks and Gordon, 1985 H.J.B. Birks and A.D. Gordon, Numerical Methods in Quaternary Pollen Analysis, Academic Press, London (1985) 289pp.

Birks and Heegaard, 2003 H.J.B. Birks and E. Heegaard, Developments in age-depth modelling of Holocene stratigraphical sequences, PAGES News 11 (2003), pp. 7-8.

Björck et al., 1996 S. Björck, B. Kromer, S. Johnsen, O. Bennike, D. Hammarlund, G. Lemdahl, G. Possnert, T.L. Rasmussen, B. Wohlfarth, C.U. Hammer and M. Spurk, Synchronized terrestrial-atmospheric deglacial records around the North-Atlantic, Science 274 (1996), pp. 1155-1160.

Björck et al., 1997 S. Björck, M. Rundgren, O. Ingolfsson and S. Funder, The Preboreal oscillation around the Nordic seas: terrestrial and lacustrine responses, Journal of Quaternary Science 12 (1997), pp. 455-465.

Black and Mooney, 2006 M.P. Black and S.D. Mooney, Holocene fire history from the Greater Blue Mountains World Heritage Area, New South Wales, Australia: the climate, humans and fire nexus, Regional Environmental Change 6 (2006), pp. 41-51

Brunelle and Anderson, 2003 A. Brunelle and R.S. Anderson, Sedimentary charcoal as an indicator of late-Holocene drought in the Sierra Nevada, California and its relevance to the future, The Holocene 13 (2003), pp. 21-28.

Brunelle and Whitlock, 2003 A. Brunelle and C. Whitlock, Postglacial fire, vegetation, and climate history in the clearwater range, Northern Idaho, USA, Quaternary Research 60 (2003), pp. 307-318.

Brunelle et al., 2005 A. Brunelle, C. Whitlock, P. Bartlein and K. Kipfmueller, Holocene fire and vegetation along environmental gradients in the Northern Rocky Mountains, Quaternary Science Reviews 24 (2005), pp. 2281-2300. 
Buhk and Hensen, 2006 C. Buhk and I. Hensen, "Fire seeders" during early post-fire succession and their quantitative importance in south-eastern Spain, Journal of Arid Environments 66 (2) (2006), pp. 193-209.

Cacho et al., 2006 I. Cacho, N. Shackleton, H. Elderfield, F.J. Sierro and J.O. Grimalt, Glacial rapid variability in deep-water temperature and delta O-18 from the Western Mediterranean Sea, Quaternary Science Reviews 25 (23-24) (2006), pp. 3294-3311.

Campo et al., 2006 J. Campo, V. Andreu, E. Gimeno-García, O. González and J.L. Rubio, Occurrence of soil erosion after repeated experimental fires in a Mediterranean environment, Geomorphology 82 (3-4) (2006), pp. 376-387.

Camporeale, 2000 G. Camporeale, Sopravvivenze villanoviane nell'orientalizzante vetuloniese. In: F. Prayon and W. Rolling, Editors, Der Orient und Etruria, Pisa-Roma (2000), p. 153.

Camporeale and Giuntoli, 2000 G. Camporeale and S. Giuntoli, Il Parco archeologico dell'Accesa a Massa Marittima, Editrice Leopoldo II, Follonica (2000).

Carcaillet, 1998 C. Carcaillet, A spatially precise study of Holocene fire history, climate and human impact within the Maurienne valley, North French Alps, Journal of Ecology 86 (1998), pp. 384-396.

Carcaillet et al., 1997 C. Carcaillet, H.N. Barakat, C. Panaiotis and R. Loisel, Fire and lateHolocene expansion of Quercus ilex and Pinus pinaster on Corsica, Journal of Vegetation Science 8 (1997), pp. 85-94.

Carcaillet et al., 2001a C. Carcaillet, M. Bouvier, B. Fréchette, A.C. Larouche and P.J.H. Richard, Comparison of pollen-slide and sieving methods in lacustrine charcoal analyses for local and regional fire history, The Holocene 11 (2001), pp. 467-476.

Carcaillet et al., 2001b C. Carcaillet, Y. Bergeron, P.J.H. Richard, B. Fréchette, S. Gauthier and Y.T. Prairie, Change of fire frequency in the eastern Canadian boreal forests during the Holocene: does vegetation composition or climate trigger the fire regime?, Journal of Ecology 89 (6) (2001), pp. 930-946

Carcaillet et al., 2002 C. Carcaillet, H. Almquist, H. Asnong, R.H.W. Bradshaw, J.S. Carrión, M.-J. Gaillard, K. Gajewski, J.N. Haas, S.G. Haberle, P. Hadorn, S.D. Müller, P.J.H. Richard, I. Richoz, M. Rösch, M.F. Sánchez Goñi, H. von Stedingk, A.C. Stevenson, B. Talon, C. Tardy, W. Tinner, E. Tryterud, L. Wick and K.J. Willis, Holocene biomass burning and global dynamics of the carbon cycle, Chemosphere 49 (8) (2002), pp. 845-863.

Caroli and Caldara, 2006 I. Caroli and M. Caldara, Vegetation history of Lago Battaglia (eastern Gargano coast, Apulia, Italy) during the middle-late Holocene, Vegetation History and Archaeobotany 16 (4) (2006), pp. 317-327.

Carrión, 2002 J.S. Carrión, Patterns and processes of Late Quaternary environmental change in a montane region of southwestern Europe, Quaternary Science Reviews 21 (18/19) (2002), pp. 2047-2066. 
Carrión et al., 2003 J.S. Carrión, P. Sánchez-Gómez, J. Mota and C. Chaín, Fire and grazing are contingent on the Holocene vegetation dynamics of Sierra de Gádor, southern Spain, The Holocene 13 (2003), pp. 839-849.

Carrión et al., 2007 J.S. Carrión, N. Fuentes, P. González Sampériz, L. Sánchez Quirante, J.C. Finlayson, S. Fernández and A. Andrade, Holocene environmental change in a montane region of southern Europe with a long history of human settlement, Quaternary Science Reviews 26 (2007), pp. 1455-1475.

Cary et al., 2006 G.J. Cary, R.E. Keane, R.H. Gardner, S. Lavorel, M.D. Flannigan, I.D. Davies, C. Li, J.M. Lenihan, T.S. Rupp and F. Mouillot, Comparison of the sensitivity of landscape-fire-succession models to variation in terrain, fuel pattern, climate and weather, Landscape Ecology 21 (2006), pp. 121-137.

Clark, 1988 J.S. Clark, Particle motion and the theory of charcoal analysis: source area, transport, deposition, and sampling, Quaternary Research 30 (1988), pp. 67-80.

Clark and Royall, 1996 J.S. Clark and P.D. Royall, Local and regional sediment charcoal evidence for fire regimes in presettlement north-eastern North America, Journal of Ecology 84 (1996), pp. 365-383.

Clark et al., 1989 J.S. Clark, J. Merkt and H. Müller, Post-glacial fire, vegetation, and human history on the northern alpine forelands, south-western Germany, Journal of Ecology 77 (1989), pp. 897-925.

Clark et al., 1996 J.S. Clark, P.D. Royall and C. Chumbley, The role of fire during climate change in an eastern deciduous forest at Devil's Bathtub, New York, Ecology 77 (1996), pp. 2148-2166.

Colombaroli, 2007 Colombaroli, D., 2007. Long-term fire and vegetation dynamics of Mediterranean ecosystems: a case study from the peri-Adriatic region. Ph.D. Thesis, University of Bern, Bern, p. 138.

Colombaroli et al., 2007 D. Colombaroli, A. Marchetto and W. Tinner, Long-term interactions between Mediterranean climate, vegetation and fire regime at Lago di Massaciuccoli (Tuscany, Italy), Journal of Ecology 95 (4) (2007), pp. 755-770.

Colombaroli et al., in press Colombaroli, D., Vannière, B., Chapron, E., Magny, M., Tinner, W. High temporal resolution study of climate, vegetation composition, fire and human impact interactions during the Mesolithic-Neolithic transition at Lago dell'Accesa (Tuscany, Italy). The Holocene, in press.

Conedera and Tinner, $2000 \mathrm{M}$. Conedera and W. Tinner, The interaction between forest fires and human activity in southern Switzerland. In: J.L. Innes, M. Beniston and M.M. Verstraete, Editors, Biomass Burning and its Inter-relationships With the Climate System, Dordrecht, Kluwer (2000), pp. 247-261

Cramer, $2001 \mathrm{~W}$. Cramer, Fire ecology, Mediterranean forests and global change, Forestry Ecolology Management 147 (1) (2001), pp. 1-2. 
de Vernal and Hillaire Marcel, 2006 A. de Vernal and C. Hillaire Marcel, Provincialism in trends and high frequency changes in the northwest North Atlantic during the Holocene, Global and Planetary Change 54 (3/4) (2006), pp. 263-290.

Disnar et al., 2003 J.R. Disnar, B. Guillet, D. Keravis, C. Di-Giovanni and D. Sebag., Soil OM (SOM) characterization by Rock-Eval pyrolysis: scope and limitations, Organic Geochemistry 34 (2003), pp. 327-343.

Drescher-Schneider et al., 2007 R. Drescher-Schneider, J. de Beaulieu, M. Magny, A.V. Walter-Simonnet, G. Bossuet, L. Millet, E. Brugiapaglia and A. Drescher, Vegetation history, climate and human impact over the last 15,000 years at Lago dell'Accesa (Tuscany, Central Italy), Vegetation History and Archaeobotany 16 (2007), pp. 279-299.

Espitalié et al., 1985a J. Espitalié, G. Deroo and F. Marquis, La pyrolyse Rock Eval et ses applications. 2de partie, Revue De L Institut Francais Du Petrole 40 (1985), pp. 755-784.

Espitalié et al., 1985b J. Espitalié, G. Deroo and F. Marquis, La pyrolyse Rock Eval et ses applications. 3ème partie, Revue De L Institut Francais Du Petrole 41 (1985), pp. 73-89.

Finsinger and Tinner, 2005 W. Finsinger and W. Tinner, Minimum count sums for charcoalconcentration estimates in pollen slides: accuracy and potential errors, The Holocene 15 (2005), pp. 293-297.

Finsinger et al., 2006 W. Finsinger, W. Tinner, W.O. van der Knaap and B. Ammann, The expansion of hazel (Corylus avellana L.) in the southern Alps: a key for understanding its early Holocene history in Europe?, Quaternary Science Reviews 25 (5/6) (2006), pp. 612631 .

Flannigan et al., 1998 M. Flannigan, Y. Bergeron, O. Engelmark and M. Wotton, Future wildfire in the northern forests: less than global warming would suggest, Journal of Vegetation Science 9 (1998), pp. 469-476.

Gardner and Whitlock, 2001 J.J. Gardner and C. Whitlock, Charcoal accumulation following a recent fire in the Cascade Range, northwestern USA, and its relevance for fire-history studies, The Holocene 11 (5) (2001), pp. 541-549.

Gavin et al., 2003a D.G. Gavin, L.B. Brubaker and K.P. Lertzman, Holocene fire history of a coastal temperate rain forest based on soil charcoal radiocarbon dates, Ecology 84 (2003), pp. 186-201.

Gavin et al., 2003b D.G. Gavin, L.B. Brubaker and K.P. Lertzman, An 1800-year record of the spatial and temporal distribution of fire from the west coast of Vancouver Island, Canada, Canadian Journal of Forest Research 33 (2003), pp. 573-586.

Gavin et al., 2006 D.G. Gavin, F.S. Hu, K. Lertzman and P. Corbett, Weak climatic control of stand-scale fire history during the late Holocene, Ecology 87 (7) (2006), pp. 1722-1732.

Giraudi, 1998 C. Giraudi, Late Pleistocene and Holocene lake-level variations in Fucino Lake (Abruzzo, central Italy) inferred from geological, archaeological and historical data. In: S.P. Harrison, B. Frenzel, U. Huckried and M. Weiss, Editors, Palaeohydrology as Reflected in 
Lake-Level Changes as Climatic Evidence for Holocene Times vol. 25, Paläoklimaforschung (1998), pp. 1-17.

Gobet et al., 2003 E. Gobet, W. Tinner, P.A. Hochuli, J.F.N. van Leeuwen and B. Ammann, Middle to Late Holocene vegetation history of the Upper Engadine (Swiss Alps): the role of man and fire, Vegetation History and Archaeobotany 12 (3) (2003), pp. 143-163.

Grimm, 1992 Grimm, E.C., 1992. Tilia and Tilia-graph: pollen spreadsheet and graphics programs. Programs and Abstracts, 8th International Palynological Congress, Aix-enProvence, September 6-12, 1992, p. 56.

Grund et al., 2005 K. Grund, M. Conedera, H. Schroder and G.R. Walther, The role of fire in the invasion process of evergreen broad-leaved species, Basic and Applied Ecology 6 (2005), pp. $47-56$.

Haas et al., 1998 J.N. Haas, I. Richoz, W. Tinner and L. Wick, Synchronous Holocene climatic oscillations recorded on the Swiss Plateau and at timberline in the Alps, The Holocene 8 (1998), pp. 301-309.

Hadjibiros, 2001 K. Hadjibiros, Setting priorities for wildfire suppression policy in Greece, using a relation between yearly burned areas and recovery time, Global Nest: The International Journal 3 (1) (2001), pp. 37-43.

Heegaard et al., 2005 E. Heegaard, H.J.B. Birks and R. Telford, Relationships between calibrated ages and depth in stratigraphical sequences: an estimation procedure by mixedeffect regression, The Holocene 15 (2005), pp. 612-618.

Heinl et al., 2006 M. Heinl, P. Frost, C. Vanderpost and J. Sliva, Fire activity on drylands and floodplains in the southern Okavango Delta, Botswana, Journal of Arid Environments 68 (1) (2006), pp. 77-87.

Heyerdahl et al., 2002 E. Heyerdahl, L. Brubaker and J.K. Agee, Annual and decadal climate forcing of historical fire regimes in the interior Pacific Northwest, USA, The Holocene 12 (5) (2002), pp. 597-604.

Higuera et al., 2005 P.E. Higuera, D.G. Sprugel and L.B. Brubaker, Reconstructing fire regimes with charcoal from small-hollow sediments: a calibration with tree-ring records of fire, The Holocene 15 (2005), pp. 238-251.

Hu et al., 2006 F.S. Hu, L.B. Brubaker, D.G. Gavin, P.E. Higuera, J.A. Lynch, T.S. Rupp and W. Tinner, How climate and vegetation influence the fire regime of the Alaskan boreal biome: the Holocene perspective, Mitigation and Adaptation Strategies for Global Change 11 (2006), pp. 829-846.

Huntley, 1993 B. Huntley, Rapid early-Holocene migration and high abundance of hazel (Corylus avellana L.): alternative hypotheses. In: F.M. Chambers, Editor, Climate Change and Human Impact on the Landscape, Chapman \& Hall, London (1993), pp. 205-215.

Juggins, 1991 Juggins, S., 1991. Zone Version 1.2. DOS program for the zonation (constrained clustering) of palaeoecological data. ECRC, UCL, London, unpublished. 
Keeley et al., 2006 J.E. Keeley, C.J. Fotheringham and M. Baer-Keeley, Demographic patterns of postfire regeneration in Mediterranean-climate shrublands of California, Ecological Monographs 76 (2) (2006), pp. 235-255.

Kutzbach and Webb, 1993 J.E. Kutzbach and T. Webb III, Conceptual basis for understanding late-Quaternary climates. In: H.E. Wright Jr. et al., Editors, Global Climates since the Last Glacial Maximum, University of Minnesota Press, Minneapolis (1993), pp. 511.

Lallier-Vergès et al., 1993 E. Lallier-Vergès, A. Sifeddine, J.L. de Beaulieu, M. Reille, N. Tribovillard, P. Bertrand, T. Mongenot, N. Thouveny, J.R. Disnar and B. Guillet, Sensibilité de la sédimentation organique aux variations climatiques du Tardi-Würm et de l'Holocène-le lac du Bouchet (Haute-Loire, France), Bullettin Société Géologique France 164 (1993), pp. $661-673$.

Lobell, 2002 J.A Lobell, Etruscan Pompeii (Largest Etruscan settlement ever found discovered in the Tuscan plain near Lake Accesa, Italy), Archaeology 55 (2002), p. 12.

Long and Whitlock, 2002 C. Long and C. Whitlock, Fire and vegetation history from the coastal rain forest of the western Oregon coast range, Quaternary Research 58 (3) (2002), pp. $215-225$.

Long et al., 1998 C.J. Long, C. Whitlock, P.J. Bartlein and S.H. Millspaugh, A 9000-year fire history from the Oregon Coast Range, based on a high-resolution charcoal study, Canadian Journal of Forest Research-Revue Canadienne De Recherche Forestiere 28 (1998), pp. 774-787.

Lynch et al., 2003 J.A. Lynch, J.S. Clark, N.H. Bigelow, M.E. Edwards and B.P. Finney, Geographic and temporal variations in fire history in boreal ecosystems of Alaska, Journal of Geophysical Research 108 (2003), pp. 1-17.

Lynch et al., 2004 J.A. Lynch, J.S. Clark and B.J. Stocks, Charcoal production, dispersal, and deposition from the Fort Providence experimental fire: interpreting fire regimes from charcoal records in boreal forests, Canadian Journal of Forest Research-Revue Canadienne De Recherche Forestiere 34 (2004), pp. 1642-1656.

MacDonald et al., 1991 G.M. MacDonald, C.P.S. Larsen, J.M. Szeicz and K.A. Moser, The reconstruction of boreal forest fire history from lake sediments: a comparison of charcoal, pollen, sedimentological, and geochemical indices, Quaternary Science Reviews 10 (1991), pp. 53-71.

Magny, 1998 M. Magny, Reconstruction of Holocene lake-level changes in the Jura (France): methods and results. In: S.P. Harrison, B. Frenzel, U. Huckried and M. Weiss, Editors, Palaeohydrology as Reflected in Lake-Level Changes as Climatic Evidence for Holocene Times vol. 25, Paläoklimaforschung (1998), pp. 67-85.

Magny et al., 2003 M. Magny, C. Bégeot, J. Guiot and O. Peyron, Contrasting patterns of hydrological changes in Europe in response to Holocene climate cooling phases, Quaternary Science Reviews 22 (2003), pp. 1589-1596. 
Magny et al., 2006 M. Magny, J.L. de Beaulieu, R. Drescher-Schneider, B. Vanniere, A.V. Walter-Simonnet, L. Millet, G. Bossuet and O. Peyron, Climatic oscillations in central Italy during the Last Glacial-Holocene transition: the record from Lake Accesa, Journal of Quaternary Science 21 (2006), pp. 311-320.

Magny et al., 2007 M. Magny, J.L. de Beaulieu, R. Drescher-Schneider, B. Vannière, A.-V. Walter-Simonnet, Y. Miras, L. Millet, G. Bossuet, O. Peyron, E. Bruggiapaglia and A. Leroux, Holocene climate changes in central Mediterranean as recorded by lake-level fluctuations at Lake Accesa (Tuscany, Italy), Quaternary Science Reviews 26 (2007), pp. 1736-1758.

Malone, 2003 C. Malone, The Italian Neolithic: a synthesis of research, Journal of World Prehistory 17 (2003), pp. 235-312.

Marlon et al., 2006 J. Marlon, P.J. Bartlein and C. Whitlock, Fire-fuel-climate linkages in the northwestern USA during the Holocene, The Holocene 16 (8) (2006), pp. 1059-1071.

Matter, 2005 Matter, C., 2005. Seismic to core correlation in the Lago dell'Acessa, Tuscany. Diploma Thesis, ETH Zürich, Department of Earth Science, p. 121.

Merciai, 1933 G. Merciai, Il Lago dell'Accesa presso Massa Marittima, Societa Toscana di Scienze Naturali, Memorie, Serie B 43 (1933), pp. 29-50.

Meyers and Lallier-Vergès, 1999 P. Meyers and E. Lallier-Vergès, Lacustrine sedimentary organic matter records of Late Quaternary paleoclimates, Journal of Paleolimnology 21 (1999), pp. 345-372.

Millet et al., 2007 Millet, L., Vannière, B., Verneaux, V., Magny, M., Disnar, J.-R., LaggounDéfarge, F., Walter-Simonnet A.-V., Bossuet, G., Ortu, E., de Beaulieu, J.-L., 2007. Response of littoral chironomid communities and organic matter to late glacial lake-level, vegetation and climate changes at Lago dell'Accesa (Tuscany, Italy). Journal of Paleolimnology, doi:10.1007/s10933-007-9088-z.

Millspaugh et al., 2000 S. Millspaugh, C. Whitlock and P.J. Bartlein, Variations in fire frequency and climate over the past 17,000 yr in central Yellowstone National Park, Geology 28 (3) (2000), pp. 211-214.

Mooney and Maltby, 2006 S.D. Mooney and E.L. Maltby, Two proxy records revealing the late Holocene fire history at a site on the central coast of New South Wales, Australia, Austral Ecology 31 (2006), pp. 682-695.

Moore et al., 1991 P.D. Moore, J.A. Webb and M.E. Collinson, Pollen Analysis (second ed), Blackwell Scientific Publications, London (1991).

Moreno, 1998 J.M. Moreno, Recent history of forest fires in Spain. In: J.M. Moreno, Editor, Large Forest Fires, Backhuys, Leiden (1998), pp. 159-185.

Moriondo et al., 2006 M. Moriondo, P. Good, R. Durao, M. Bindi, C. Giannakopoulos and J. Corte Real, Potential impact of climate change on forest fire risk in Mediterranean area, Climate Research 31 (2006), pp. 85-95. 
Mouillot et al., 2003 F. Mouillot, J.P. Ratte, R. Joffre, J.M. Moreno and S. Rambal, Some determinants of the spatio-temporal fire cycle in a Mediterranean landscape (Corsica, France), Landscape Ecology 18 (2003), pp. 665-674.

Nicolussi and Patzelt, 2000 K. Nicolussi and G. Patzelt, Discovery of Early Holocene wood and peat on the forefield of the Pasterze Glacier, Eastern Alps, Austria, The Holocene 10 (2) (2000), pp. 191-199.

Oldfield et al., 2003 F. Oldfield, A. Asioli, C.A. Accorsi, S. Juggins, L. Langone, T. Rolph, F. Trincardi, G. Wolff, Z. Gibbs-Eggar, L. Vigliotti, M. Frignani, K. van der Post and N. Branch, A high resolution Late-Holocene palaeo-environmental record from the central Adriatic Sea, Quaternary Science Reviews 22 (2003), pp. 319-342.

Pausas, 2004 J.G. Pausas, Changes in fire and climate in the eastern Iberian Peninsula (Mediterranean basin), Climatic Change 63 (3) (2004), pp. 337-350.

Pausas, 2006 J.G. Pausas, Simulating Mediterranean landscape pattern and vegetation dynamics under different fire regimes, Plant Ecology 187 (2006), pp. 249-259.

Pausas and Bradstock, 2007 J.G. Pausas and R.A. Bradstock, Fire persistence traits of plants along a productivity and disturbance gradient in Mediterranean shrublands of south-east Australia, Global Ecology and Biogeography 16 (2007), pp. 330-340.

Pausas and Vallejo, 1999 J.G. Pausas and R. Vallejo, The role of fire in European Mediterranean ecosystems. In: E. Chuvieco, Editor, Remote Sensing of Large Wildfires, Springer, Berlin, Germany (1999), pp. 2-16.

Peters and Higuera, 2007 M.E. Peters and P.E. Higuera, Quantifying the source area of macroscopic charcoal with a particle dispersal model, Quaternary Research 67 (2) (2007), pp. 304-310.

Pigott and Pigott, 1993 C.D. Pigott and S. Pigott, Water as a determinant of the distribution of trees at the boundary of the Mediterranean zone, Journal of Ecology 81 (1993), pp. 557-566.

Piňol et al., 1998 J. Piňol, J. Terradas and F. Lloret, Climate warming, wildfire hazard, and wildfire occurrence in coastal eastern Spain, Climatic Change 38 (1998), pp. 345-357.

Pisaric, 2002 M.F.J. Pisaric, Long-distance transport of terrestrial plant material by convection resulting from forest fires, Journal of Paleolimnology 28 (2002), pp. 349-354.

Pitkanen and Huttunen, 1999 A. Pitkanen and P. Huttunen, A 1300-year forest-fire history at a site in eastern Finland based on charcoal and pollen records in laminated lake sediment, The Holocene 9 (3) (1999), pp. 311-320.

Ramrath et al., 2000 A. Ramrath, L. Sadori and J.F.W. Negendank, Sediments from Lago di Mezzano, central Italy: a record of Lateglacial/Holocene climatic variations and anthropogenic impact, The Holocene 10 (1) (2000), pp. 87-95.

Ramsey, 2001 C. Ramsey, Development of the radiocarbon program OxCal, Radiocarbon 43 (2A) (2001), pp. 355-363. 
Reed et al., 2001 J.M. Reed, A.C. Stevenson and S. Juggins, A multi-proxy record of Holocene climatic change in southwestern Spain: the Laguna de Medina, Cadiz, The Holocene 11 (2001), pp. 707-719.

Reimer et al., 2004 P.J. Reimer, M.G.L. Baillie, E. Bard, A. Bayliss, J.W. Beck, C.J.H. Bertrand, P.G. Blackwell, C.E. Buck, G.S. Burr, K.B. Cutler, P.E. Damon, R.L. Edwards, R.G. Fairbanks, M. Friedrich, T.P. Guilderson, A.G. Hogg, K.A. Hughen, B. Kromer, F.G. McCormac, S.W. Manning, C.B. Ramsey, R.W. Reimer, S. Remmele, J.R. Southon, M. Stuiver, S. Talamo, F.W. Taylor, J. van der Plicht and C.E. Weyhenmeyer, IntCal04 terrestrial radiocarbon age calibration, 26-0 ka BP, Radiocarbon 46 (2004), pp. 1029-1058.

Rhodes, 1998 A.N. Rhodes, A method for the preparation and quantification of microscopic charcoal from terrestrial and lacustrine sediment cores, The Holocene 8 (1) (1998), pp. 113117.

Rizzotto, 1981 Rizzotto, M., 1981. Il Lago dell'Accesa (Grosseto) note floristiche e vegetazionali. Atti Soc. Tosc. Sci. Nat. Mem., Serie B, 88.

Rollins et al., 2002 M.G. Rollins, P. Morgan and T. Swetnam, Landscape-scale controls over 20th century fire occurrence in two large Rocky Mountain (USA) wilderness areas, Landscape Ecology 17 (2002), pp. 539-557.

Rolph et al., 2004 T.C. Rolph, L. Vigliotti and F. Oldfield, Mineral magnetism and geomagnetic secular variation of marine and lacustrine sediments from central Italy: timing and nature of local and regional Holocene environmental change, Quaternary Science Reviews 23 (14-15) (2004), pp. 1699-1722.

Rossignol-Strick, 1999 M. Rossignol-Strick, The Holocene climatic optimum and pollen records of sapropel 1 in the eastern Mediterranean, 9000-6000 BP, Quaternary Science Reviews 18 (1999), pp. 515-530.

Running, 2006 S.W. Running, Is global warming causing more, larger wildfires?, Science 313 (2006), pp. 927-928.

Sadori and Giardini, 2006 L. Sadori and M. Giardini, Charcoal analysis, a method to study vegetation and climate of the Holocene: the case of Lago di Pergusa (Sicily, Italy), Geobios 40 (2) (2006), pp. 173-180.

Sadori et al., 2004 L. Sadori, C. Giraudi, P. Petitti and A. Ramrath, Human impact at Lago di Mezzano (central Italy) during the Bronze Age: a multidisciplinary approach, Quaternary International 113 (2004), pp. 5-17.

Salvador et al., 2005 R. Salvador, F. Lloret, X. Pons and J. Pinol, Does fire occurrence modify the probability of being burned again? A null hypothesis test from Mediterranean ecosystems in NE Spain, Ecological Modelling 188 (2005), pp. 461-469.

Sangiorgi et al., 2002 F. Sangiorgi, L. Capotondi and H. Brinkhuis, A centennial scale organic-walled dinoflagellate cyst record of the last deglaciation in the south Adriatic sea 
(Central Mediterranean), Palaeogeographay, Palaeoclimatology, Palaeoecology 186 (2002), pp. 199-216.

Santoni et al., 2006 P.A. Santoni, A. Simeoni, J.L. Rossi, F. Bosseur, F. Morandini, X. Silvani, J.H. Balbi, D. Cancelieri and L. Rossi, Instrumentation of wildland fire: characterisation of a fire spreading through a Mediterranean shrub, Fire Safety Journal 41 (3) (2006), pp. 171-184.

Settis, 1985 S. Settis, The Land of the Etruscans from Prehistory to the Middle Ages, Scala, Firenze (1985).

Shakesby and Doerr, 2006 R.A. Shakesby and S.H. Doerr, Wildfire as a hydrological and geomorphological agent, Earth-Science Reviews 74 (2006), pp. 269-307.

Sifeddine et al., 1996 A. Sifeddine, P. Bertrant, E. Lallier-Vergès and A.J. Patience, Lacustrine organic fluxes and palaeoclimatic variations during the last $15 \mathrm{ka}$ : lac du Bouchet (Massif Central, France), Quaternary Science Reviews 15 (1996), pp. 203-211.

Stähli et al., 2006 M. Stähli, W. Finsinger, W. Tinner and B. Allgower, Wildfire history and fire ecology of the Swiss National Park (Central Alps): new evidence from charcoal, pollen and plant macrofossils, The Holocene 16 (6) (2006), pp. 805-817.

Stockmarr, 1971 J. Stockmarr, Tablets with spores used in absolute pollen analysis, Pollen et Spores 13 (1971), pp. 615-621.

Stuiver and Reimer, 1993 M. Stuiver and P.J. Reimer, Extended 14C data base and revised Calib 3.0 14C age calibration program, Radiocarbon 35 (1) (1993), pp. 215-230.

Talbot and Livingstone, 1989 M.R. Talbot and D.A. Livingstone, Hydrogen index and carbon isotopes of lacustrine organic matter as lake-level indicators, Palaeoclimatology, Palaeogeography, Palaeoecology 70 (1989), pp. 121-137.

Telesca and Lasaponara, 2006 L. Telesca and R. Lasaponara, Emergence of temporal regimes in fire sequences, Physical A Statistical Mechanics and Its Applications 360 (2) (2006), pp. $543-547$.

Telesca et al., 2007 L. Telesca, G. Amatulli, R. Lasaponaraa, M. Lovalloa and A. Santullia, Identifying spatial clustering properties of the 1997-2003 Liguria (Northern Italy) forest-fire sequence, Chaos, Solitons, and Fractals 32 (4) (2007), pp. 1364-1370.

Telford et al., 2004 R.J. Telford, E. Heegaard and H.J.B. Birks, The intercept is a poor estimate of a calibrated radiocarbon age, The Holocene 14 (2004), pp. 296-298.

Terradas et al., 1998 J. Terradas, J. Piňol and F. Lloret, Risk factors in wildfires along the Mediterranean coast of the Iberian Peninsula. In: L. Trabaud, Editor, Fire Management and Landscape Ecology, International Association of Wildland Fire, Fairfield (1998), pp. 297304. 
Tinner and $\mathrm{Hu}, 2003 \mathrm{~W}$. Tinner and F.S. Hu, Size parameters, size-class distribution and areanumber relationship of microscopic charcoal: relevance for fire reconstruction, The Holocene 13 (2003), pp. 499-505.

Tinner and Lotter, $2001 \mathrm{~W}$. Tinner and A.F. Lotter, Central European vegetation response to abrupt climate change at $8.2 \mathrm{ka}$, Geology 29 (2001), pp. 551-554.

Tinner et al., 1998 W. Tinner, M. Conedera, B. Ammann, H.W. Gäggeler, S. Gedye, R. Jones and B. Sägesser, Pollen and charcoal in lake sediments compared with historically documented forest fires in southern Switzerland since AD 1920, The Holocene 8 (1) (1998), pp. $31-42$.

Tinner et al., 1999 W. Tinner, P. Hubschmid, M. Wehrli, B. Ammann and M. Conedera, Long-term forest fire ecology and dynamics in southern Switzerland, Journal of Ecology 87 (1999), pp. 273-289.

Tinner et al., 2005 W. Tinner, M. Conedera, B. Ammann and A.F. Lotter, Fire ecology north and south of the Alps since the last ice age, The Holocene 15 (2005), pp. 1214-1226.

Tinner et al., 2006a W. Tinner, F.S. Hu, R. Beer, P. Kaltenrieder, B. Scheurer and U. Krähenbuhl, Postglacial vegetational and fire history: pollen, plant macrofossil and charcoal records from two Alaskan lakes, Vegetation History and Archaeobotany 15 (4) (2006), pp. 279-293.

Tinner et al., 2006b W. Tinner, F.S. Hu, R. Beer, P. Kaltenrieder, B. Scheurer and U. Krahenbuhl, Postglacial vegetational and fire history: pollen, plant macrofossil and charcoal records from two Alaskan lakes, Vegetation History and Archaeobotany 15 (2006), pp. 279293.

Trouet et al., 2006 V. Trouet, A.H. Taylor, A.M. Carleton and C.N. Skinner, Fire-climate interactions in forests of the American Pacific coast, Geophysical Research Letters 33 (2006), p. L18704 10.1029/2006GL027502.

UNECE-FAO Report, 2002 UNECE-FAO Report, 2002. Forest fire statistics 1999-2001. Timber Bulletin, vol. LV (2002), ECE/TIM/BULL/2002/4, New York, Geneva.

UNECE ICP-BFH Executive Report, 2004 UNECE ICP-BFH Executive Report, 2004. The condition of forests in Europe. Convention on long-range transboundary air pollution: international co-operative programme on assessment and monitoring of air pollution, effects on forests. United Nations Economic Commission for Europe, Federal Research Centre for Forestry and Forest Products, Germany.

Vannière and Martineau, 2005 B. Vannière and R. Martineau, Histoire des feux et pratiques agraires du Néolithique à l'Âge du Fer en Région Centre (France). Implications territoriales, démographiques et environnementales, Gallia Préhistoire 47 (2005), pp. 167-186.

Vannière et al., 2003 B. Vannière, G. Bossuet, A.-V. Walter-Simonet, E. Gauthier, P. Barral, C. Petit, M. Buatier and A. Daubigney, Land use change, soil erosion and alluvial dynamic in 
the lower Doubs Valley over the 1st millenium AD (Neublans, Jura, France), Journal of Archaeological Science 30 (2003), pp. 1283-1299

Vázquez et al., 2002 A. Vázquez, B. Pérez, F. Fernández-Gonzáles and J.M. Moreno, Recent fire regime characteristics and potential natural vegetation relationships in Spain, Journal of Vegetation Science 13 (2002), pp. 663-676.

Veblen and Kitzberger, 2002 T. Veblen and T. Kitzberger, Inter-hemispheric comparison of fire history: the Colorado Front Range, USA, and the Northern Patagonian Andes, Argentina, Plant Ecology 163 (2) (2002), pp. 187-207.

Whitlock and Anderson, 2003 C Whitlock and R.S. Anderson, Fire history reconstructions based on sediment records from lakes and wetlands. In: T.T. Veblen, W.L. Baker, G.

Montenegro and T.W. Swetnam, Editors, Fire and Climatic Change in Temperate Ecosystems of the Americas. Ecological Studies 160, Springer, New York (2003), pp. 3-31.

Whitlock and Larsen, 2001 C. Whitlock and C. Larsen, Charcoal as a fire proxy. In: J.P. Smol, H.J.B. Birks and W.M. Last, Editors, Tracking Environmental Change Using Lake Sediments. Terrestrial, Algal, and Siliceous Indicators, Kluwer, Dordrecht (2001), pp. 75-97.

Whitlock and Millspaugh, 1996 C. Whitlock and S.H. Millspaugh, Testing assumptions of fire history studies: an examination of modern charcoal accumulation in Yellowstone National Park, The Holocene 6 (1996), pp. 7-15.

Whitlock et al., 2003 C. Whitlock, S.L. Shafer and J. Marlon, The role of climate and vegetation change in shaping past and future fire regimes in the northwestern US and the implications for ecosystem management Source, Forest Ecology and Management 178 (2003), pp. 5-21.

Whitlock et al., 2007 C. Whitlock, P.I. Moreno and P. Bartlein, Climatic controls of Holocene fire patterns in southern South America, Quaternary Research 68 (1) (2007), pp. 28-36.

Wick and Tinner, 1997 L. Wick and W. Tinner, Vegetation changes and timberline fluctuations in the Central Alps as indicator of Holocene climatic oscillations, Arctic and Alpine Research 29 (1997), pp. 445-458.

Wick et al., 2003 L. Wick, G. Lemcke and M. Sturm, Evidence of Lateglacial and Holocene climatic change and human impact in eastern Anatolia: high-resolution pollen, charcoal, isotopic and geochemical records from the laminated sediments of Lake Van, Turkey, The Holocene 13 (5) (2003), pp. 665-675.

Zanchetta et al., 2007 G. Zanchetta, R.N. Drysdale, J.C. Hellstrom, A.E. Fallick, I. Isola, M.K. Gagan and M.T. Pareschi, Enhanced rainfall in the Western Mediterranean during deposition of sapropel S1: stalagmite evidence from Corchia cave (Central Italy), Quaternary Science Reviews 26 (2007), pp. 279-286. 
Fig. 1. (a) Geographical location of Lago dell'Accesa (Tuscany, Italy) and reference sites in central Italy. (b) Bathymetric map of Lago dell'Accesa (isobaths: $5 \mathrm{~m}$ ), location of seismic reflection profiles (white lines), extension of main seismic facies and locations of sediment cores. (c) High-resolution seismic profile illustrating of the basin-fill stratigraphy, main seismic facies, basin-wide reflectors (R1 to R7), and the location of piston core AC05-B. Reflector R1 shows an on-lap configuration in the deep basin, suggesting the occurrence of a turbidite deposit associated with a sediment slump reworking part of the NW slope. Reflectors $\mathrm{R} 2, \mathrm{R} 3$, and R4 have a slightly divergent configuration towards the NW, suggesting a main sediment supply originating from the springs. In addition, towards the SE a former littoral facies is buried bellow R3 and R4 along the SE part of the basin. Reflectors R5, R6, and R7 are comparatively less continuous, and R5 is characterised by a different inclination than R6 and R7. This specific basin-fill geometry suggests that deep-water sedimentation was affected by lake-level fluctuations. (d) Age-depth relationship of master core AC05-B based on ${ }^{14} \mathrm{C}$ age ranges (Table 1).

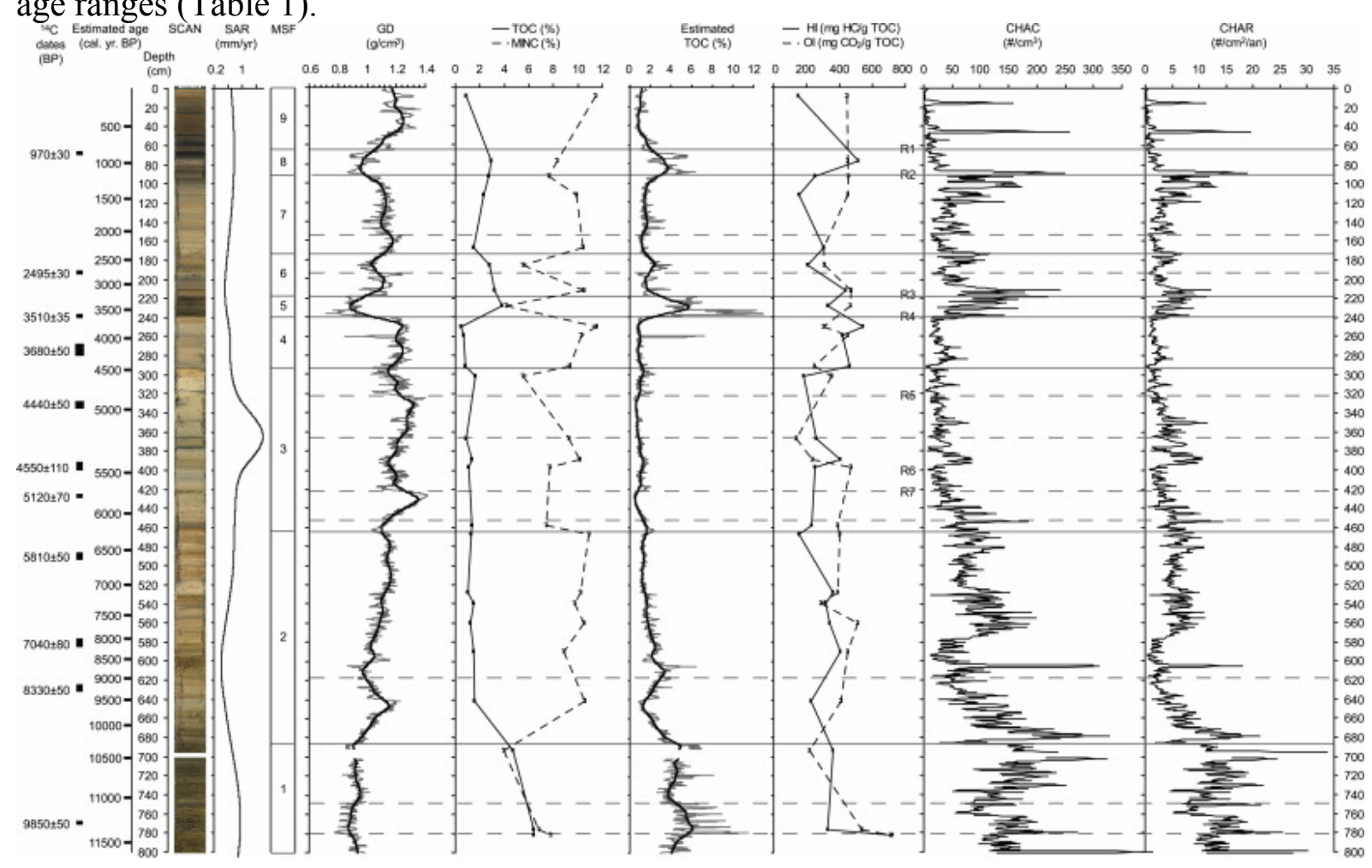

Fig. 2. Lithology, sedimentation accumulation rate (SAR), main sedimentary facies (MSF), gamma density (GD), total organic carbon (TOC), mineral carbon (MINC), TOC estimated from GD values (see Fig. 6), hydrogen index (HI), oxygen index (OI), macroscopic charcoal concentration (CHAC) and macroscopic charcoal accumulation rate (CHAR) high-resolution diagram (depth scale) from Lago dell'Accesa (core AC05-B). Estimated age and positions of AMS radiocarbon dates and seismic reference layers R1 to R7 (see Fig. 1c) are indicated. Changes in sediment bulk density match high-amplitude reflectors (R1 to R7) with use of a mean sediment Pwave velocity of $1.5 \mathrm{~km} / \mathrm{s}$. MSF1: laminated fine calcareous and organic silty clays; MSF2: laminated calcareous silt; MSF3 and 4: coarsely laminated calcareous clayey silt; MSF5: laminated fine organic silty clays; MSF6: laminated calcareous and organic silty clays; MSF7: coarsely laminated calcareous silt; MSF8: laminated fine calcareous and organic silty clays; and MSF9: laminated fine calcareous clays. 


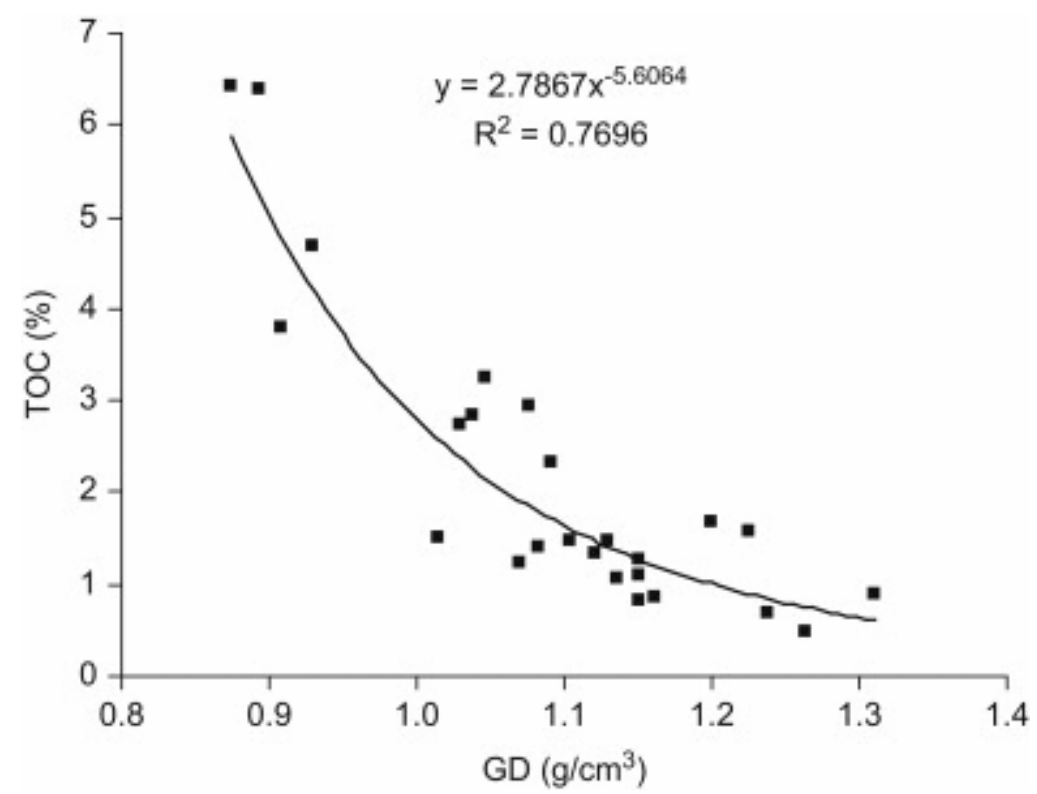

Fig. 3. Correlation diagram of total organic carbon (TOC) versus gamma density (GD) values.

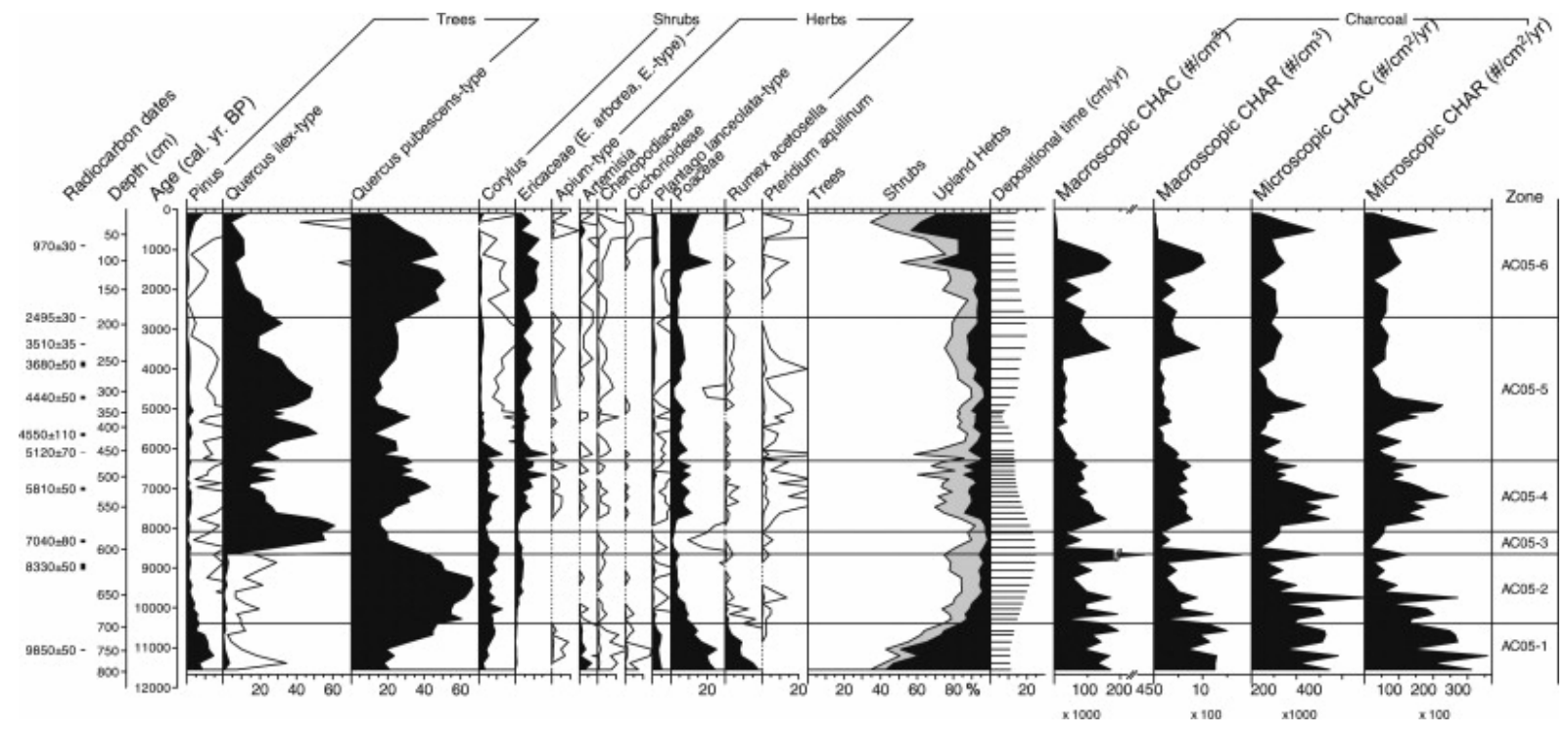

Fig. 4. Age scale diagram of pollen and charcoal data from Lago dell'Accesa (core AC05-B). The simplified pollen diagram is in percentages. Microscopic charcoal and macroscopic charcoal are shown in concentration (CHAC) and influx (CHAR). Sedimentary depths and positions of AMS radiocarbon dates are indicated. 


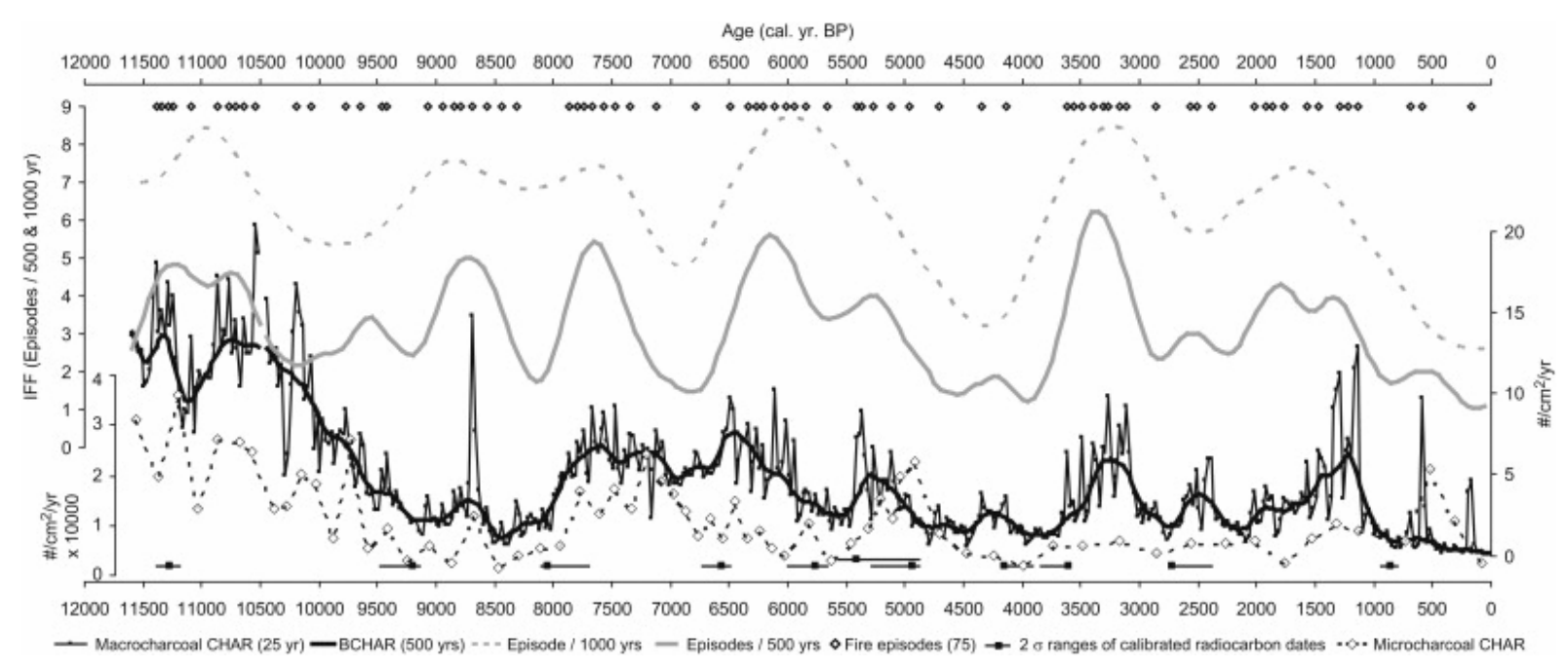

Fig. 5. Macroscopic charcoal accumulation rate (CHAR; re-sampled at 25 yr constant time interval) with background (BCHAR); locally weighted regression with a time window of 500 yrs) from Lago dell'Accesa AC05-B master core. The " $\diamond$ " symbols represent identified charcoal episodes for a threshold values (TV) of 0.7. Inferred fire frequencies (IFF) with a 500- and 1000-yr smoothing window were calculated for residual peak distributions. Lowresolution microscopic charcoal particles influx are plotted for tendency comparison.

Horizontal black bars indicate 2 S.D. ranges of radiocarbon dates on plant macrofossils.

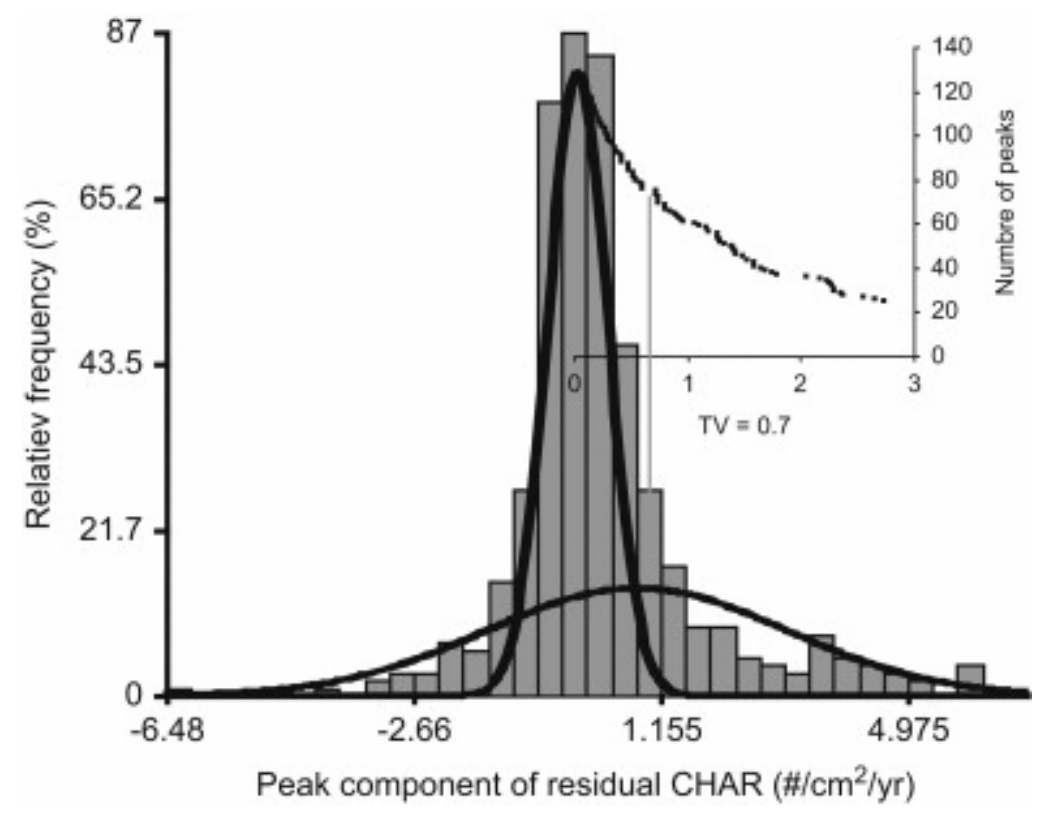

Fig. 6. Frequency distribution of the CHAR residuals with fitted curves from a Gaussian mixture model (here two sub-distributions with, respectively, a mean of -0.12 and 0.793 , a variance of 0.217 and 5.41, explaining $53.8 \%$ and $46.2 \%$ of the values distribution; Gavin et al., 2006). The upper limits of the first distribution $(95 \% ; 0.645)$ can be considered the upper limit of "noise"-related variation. Insets show how the numbers of identified peaks vary with changing thresholds. The left $y$-axis shows the frequency of the peak component values (resampled data), and the right $y$-axis shows the numbers of fire episodes. The vertical dotted line shows the threshold value (0.7) chosen to identify charcoal peaks most likely due to local fire episodes. 


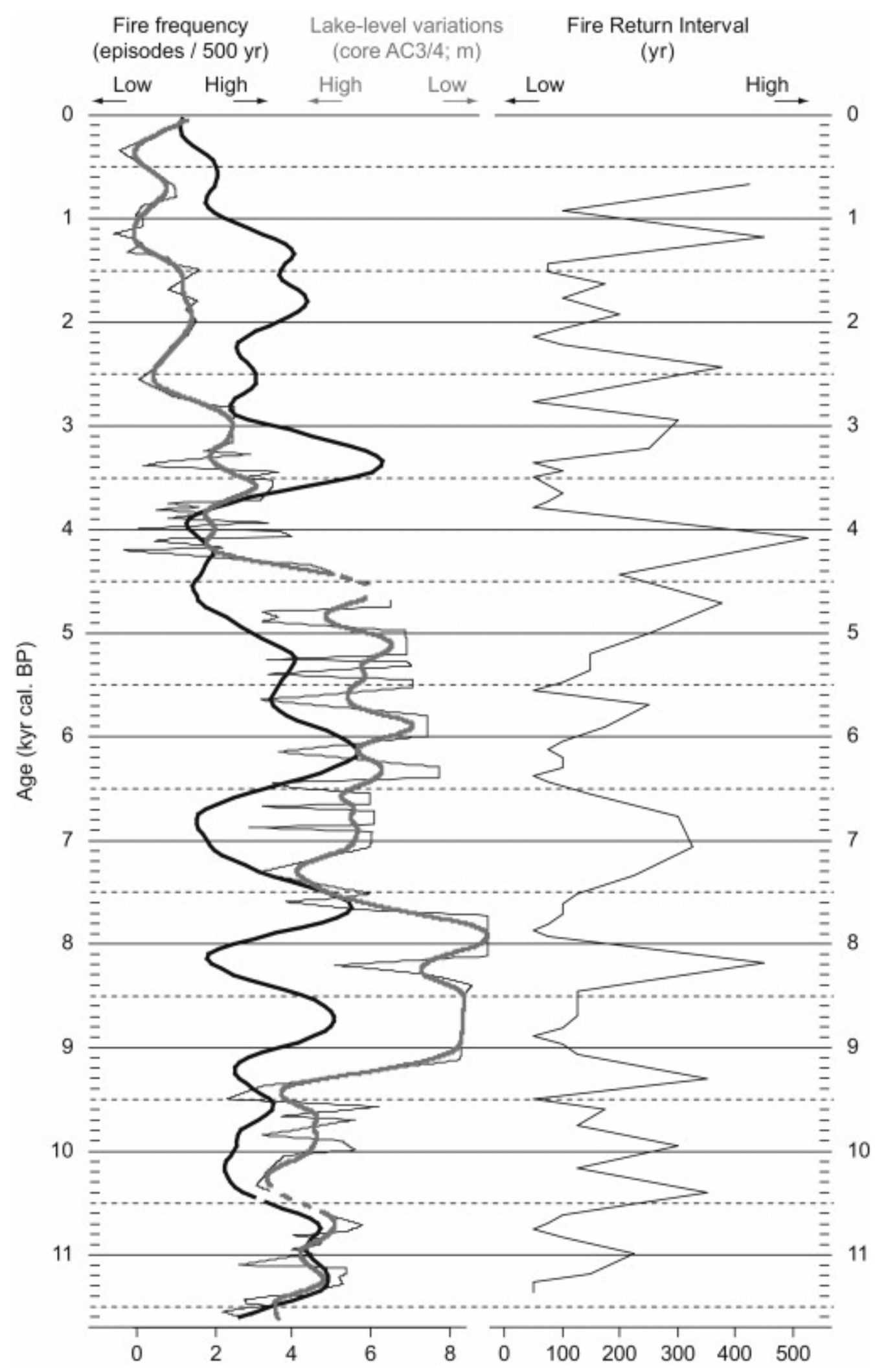

Fig. 7. Comparison between fire frequency per $500 \mathrm{yr}$ (core AC05B), fire return interval (FRI; core AC05B), and lake-level reconstruction (raw data and tendency on a $500 \mathrm{yr}$ running time window; littoral cores AC3/4; Magny et al., 2007) from Lago dell'Accesa. 


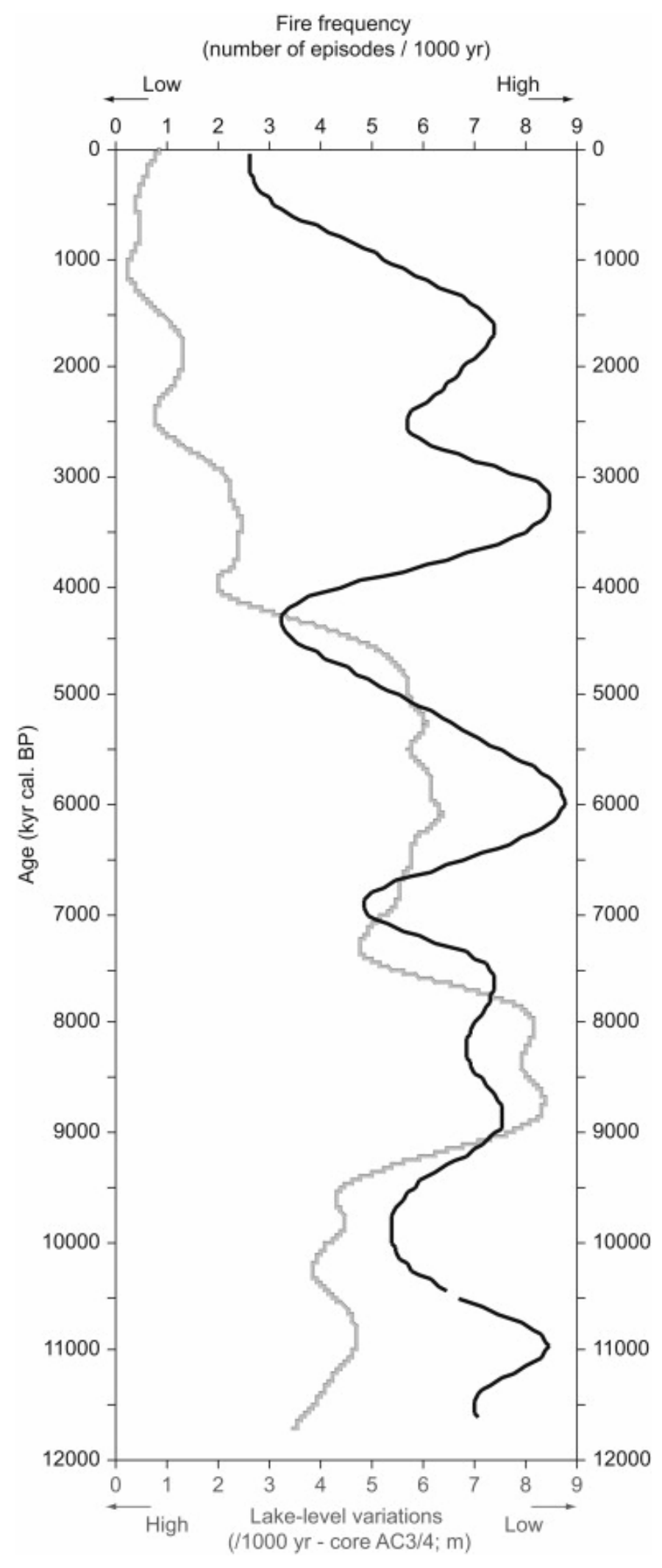

Fig. 8. Comparison (grey bands) of sedimentary charcoal series (CHAR: charcoal accumulation rate) from (1) Lago dell'Accesa, this paper, (2) Lago di Massaciuccoli, northcentral Italy, Colombaroli et al. (in press), (3) Lago di Mezzano, central Italy, Sadori et al. (2004), (4) Battagla, south-eastern Italy, Caroli and Caldara (2006), and (5) Lago di Pergusa, Sicily, Italy, Sadori and Giardini (2006). Black boxes identified high charcoal input in sedimentary sequences and black points indicate slight charcoal input. 

(1)
(2) (3) (4) (5)

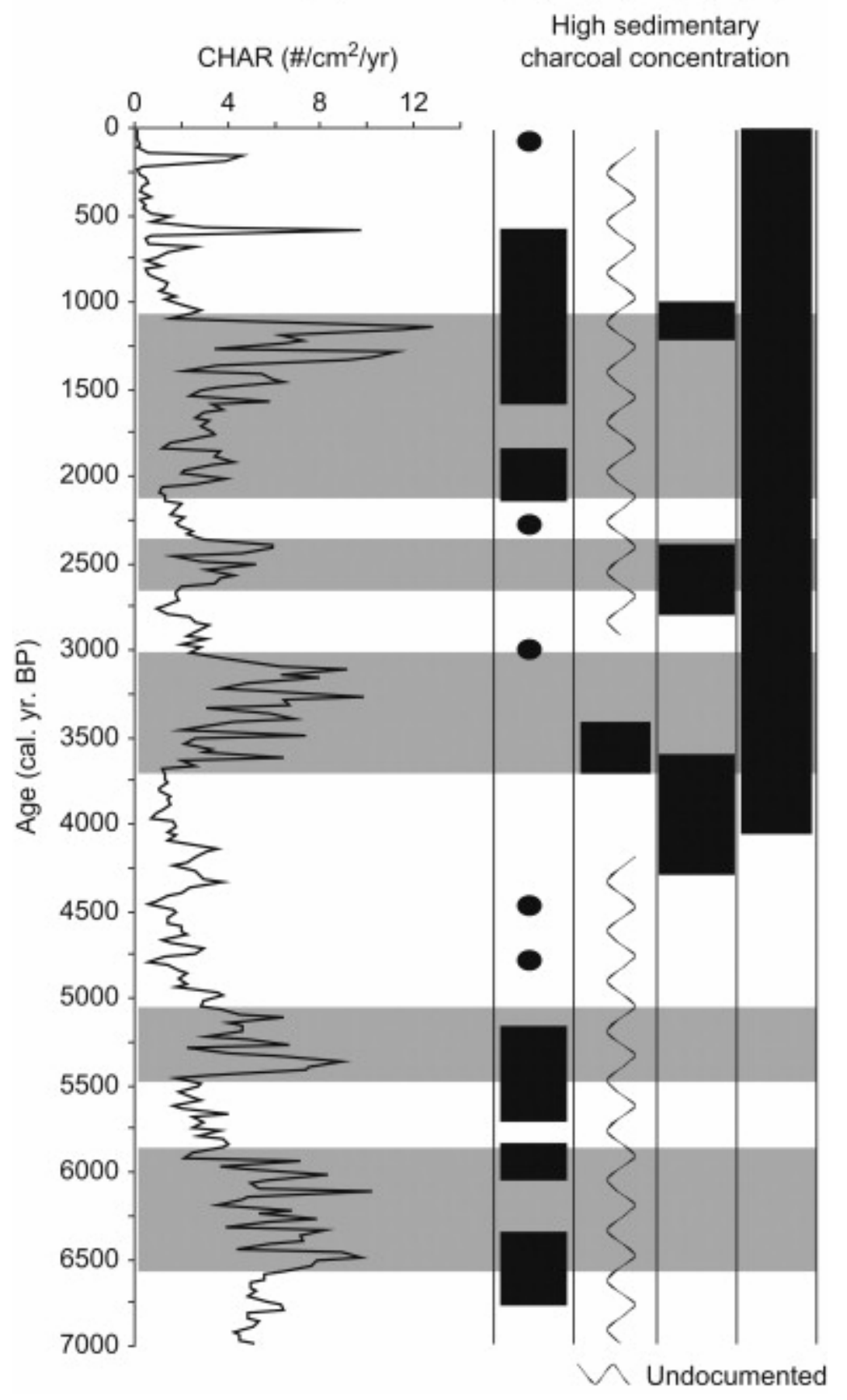

Fig. 9. Comparison between fire frequency per $1000 \mathrm{yr}$ (core AC05B), lake-level reconstruction smoothed with a 1000 yr window (cores AC3/4; Magny et al., 2007) from Lago dell' Accesa. 
Table 1.

AMS radiocarbon dates from cores AC05 of Lago dell'Accesa (Tuscany, Italy) used for chronology

\begin{tabular}{|c|c|c|c|c|c|}
\hline $\begin{array}{l}\text { Sample } \\
\text { ID }\end{array}$ & Lab. code & Material & $\begin{array}{l}\text { AMS radiocarbon } \\
\text { date } B P\end{array}$ & $\begin{array}{l}\text { Master core } \\
\text { depth }(\mathrm{cm})\end{array}$ & $\begin{array}{l}\text { Cal. yr BP 95\% } \\
\text { limits }^{\text {a }}\end{array}$ \\
\hline P7-60 & $\begin{array}{l}\text { POZ- } \\
14759\end{array}$ & Wood & $970 \pm 30$ & $66.5-67.5$ & $795-933$ \\
\hline B1.2 99 & $\begin{array}{l}\text { POZ- } \\
12334\end{array}$ & Wood & $2495 \pm 30$ & 191-192 & $2378-2732$ \\
\hline $\mathrm{C} 16-33$ & POZ14758 & Wood & $3510 \pm 35$ & $237-238$ & $3693-3876$ \\
\hline B1.4 35.5 & $\begin{array}{l}\text { POZ- } \\
16242\end{array}$ & Charcoal & $3680 \pm 50$ & $267.5-277.5$ & $3879-4151$ \\
\hline B1.5 7.5 & $\begin{array}{l}\text { POZ- } \\
16243\end{array}$ & $\begin{array}{l}\text { Bud } \\
\text { scale }\end{array}$ & $4440 \pm 50$ & $328-333$ & $4873-5285$ \\
\hline $\begin{array}{l}\text { BB1.4 } \\
57.5\end{array}$ & $\begin{array}{l}\text { POZ- } \\
16248\end{array}$ & $\begin{array}{l}\text { Bud } \\
\text { scale }\end{array}$ & $4550 \pm 110$ & $392-397$ & $4874-5572$ \\
\hline $\begin{array}{l}\text { BB } 1.5 \\
4.5\end{array}$ & $\begin{array}{l}\text { POZ- } \\
16249\end{array}$ & $\begin{array}{l}\text { Bud } \\
\text { scale }\end{array}$ & $5120 \pm 70$ & $425.5-426.5$ & 5661-5997 \\
\hline $\begin{array}{l}\text { BB } 1.5 \\
67.5\end{array}$ & $\begin{array}{l}\text { POZ- } \\
16250\end{array}$ & $\begin{array}{l}\text { Bud } \\
\text { scale }\end{array}$ & $5810 \pm 50$ & $486.5-491.5$ & $6493-6734$ \\
\hline $\begin{array}{l}B 1.7 \\
22.5^{b}\end{array}$ & $\begin{array}{l}\text { POZ- } \\
16244\end{array}$ & Wood & $3840 \pm 100$ & $532-537$ & $3933-4520$ \\
\hline B1.7 67.5 & $\begin{array}{l}\text { POZ- } \\
16245\end{array}$ & Wood & $7040 \pm 80$ & $577-582$ & $7697-7998$ \\
\hline B1.8 32.5 & $\begin{array}{l}\text { POZ- } \\
16247\end{array}$ & Leaves & $8330 \pm 50$ & $625-630$ & $9141-9472$ \\
\hline B1.9 68 & $\begin{array}{l}\text { POZ- } \\
11448\end{array}$ & Wood & $9850 \pm 50$ & $768-769$ & 11191-11389 \\
\hline
\end{tabular}

${ }^{a}$ Calibrated with CALIB Rev 5.0.2 (intcal04.14c; Stuiver and Reimer, 1993; Reimer et al., 2004).

${ }^{\mathrm{b}}$ Rejected data. 